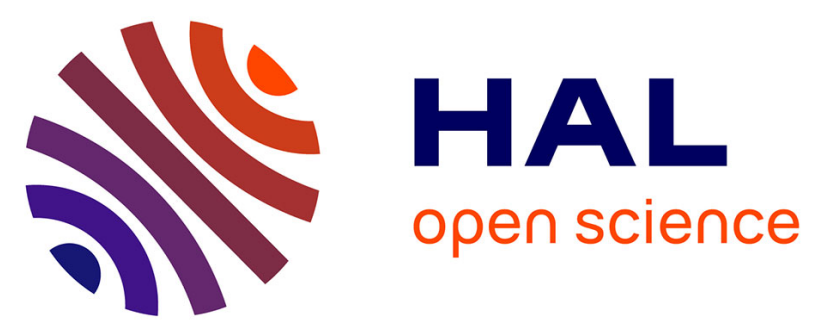

\title{
The court of 'Abd-ur-Raḥīm Khān-i Khānān as a bridge between Iranian and Indian cultural traditions
}

\author{
Corinne Lefèvre
}

\section{To cite this version:}

Corinne Lefèvre. The court of 'Abd-ur-Rahīm Khān-i Khānān as a bridge between Iranian and Indian cultural traditions. Allison Busch et Thomas de Bruijn. Culture and Circulation. Literatures in Motion in Early Modern India, E. J. Brill, p. 75-106, 2014, 978-90-04-26447-2. halshs-01956007

\section{HAL Id: halshs-01956007 https://shs.hal.science/halshs-01956007}

Submitted on 4 Jan 2019

HAL is a multi-disciplinary open access archive for the deposit and dissemination of scientific research documents, whether they are published or not. The documents may come from teaching and research institutions in France or abroad, or from public or private research centers.
L'archive ouverte pluridisciplinaire HAL, est destinée au dépôt et à la diffusion de documents scientifiques de niveau recherche, publiés ou non, émanant des établissements d'enseignement et de recherche français ou étrangers, des laboratoires publics ou privés. 


\section{Culture and Circulation}

Literature in Motion in Early Modern India

Edited by

Thomas de Bruijn and Allison Busch

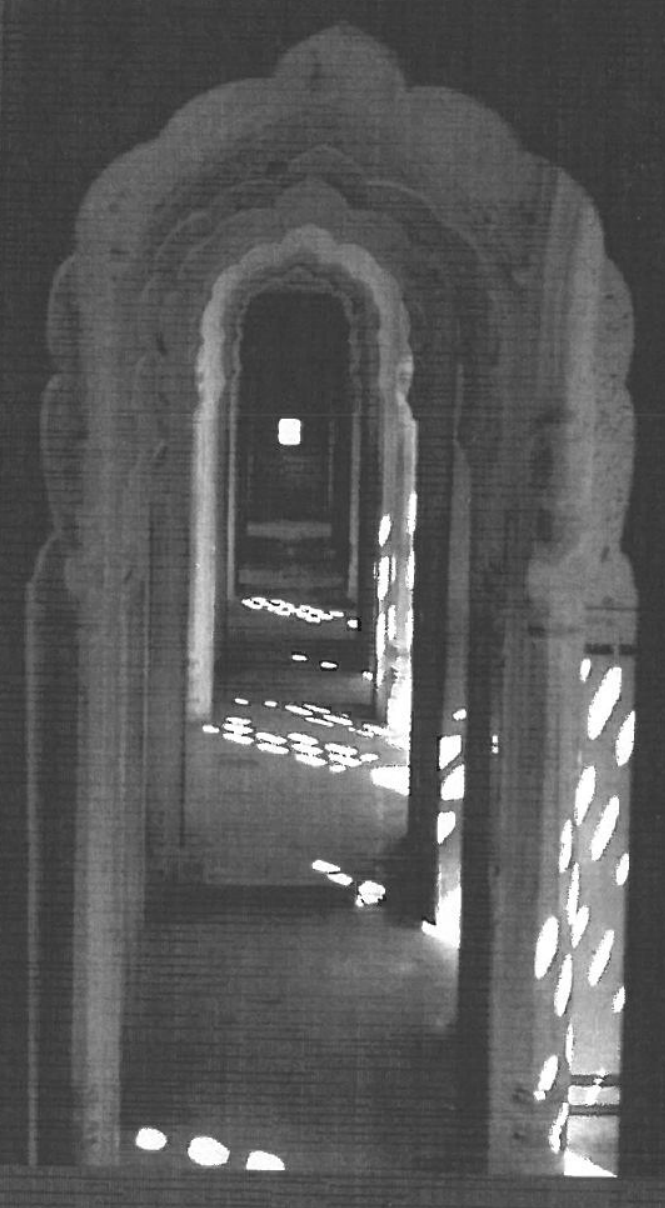

BRILL 


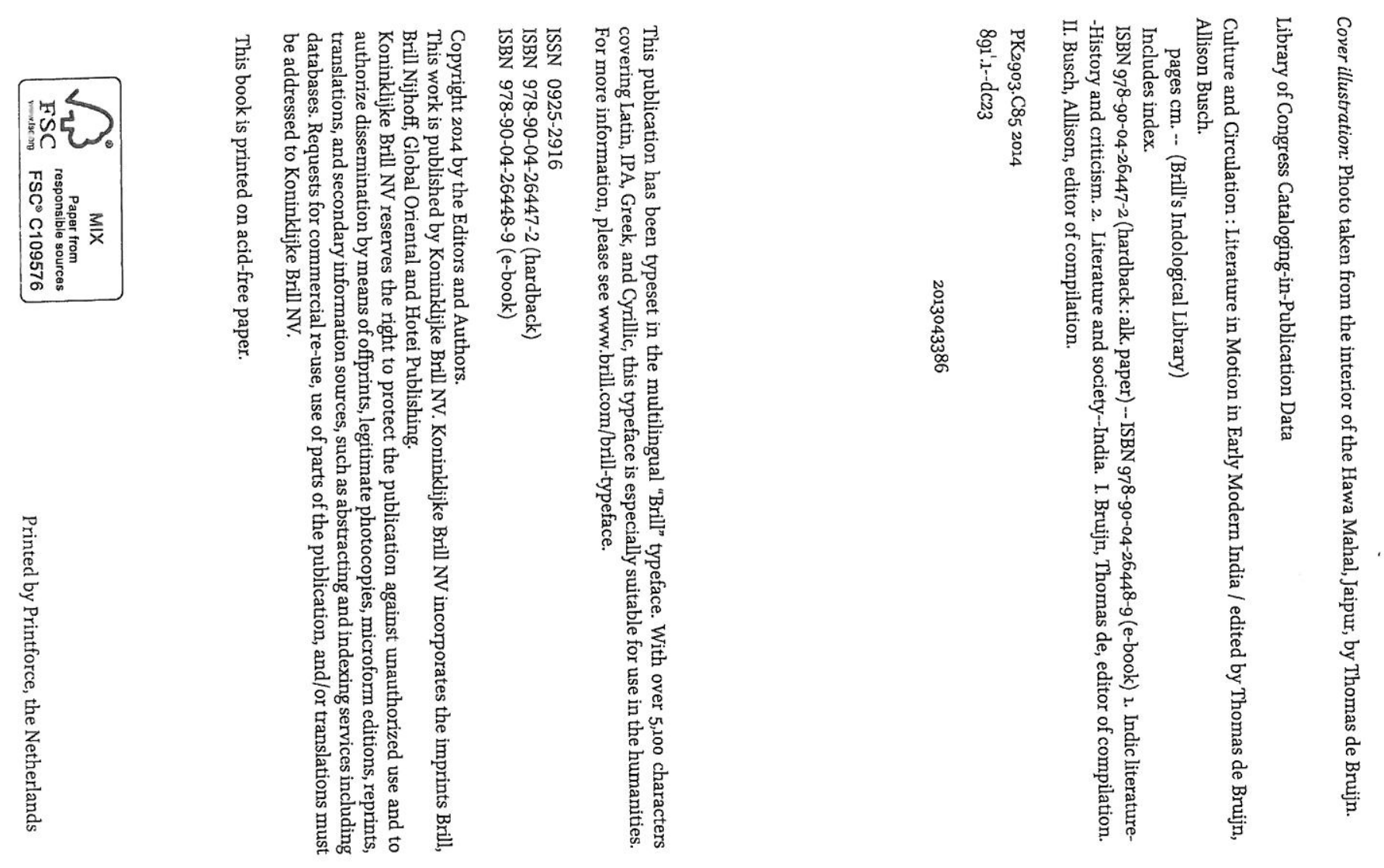

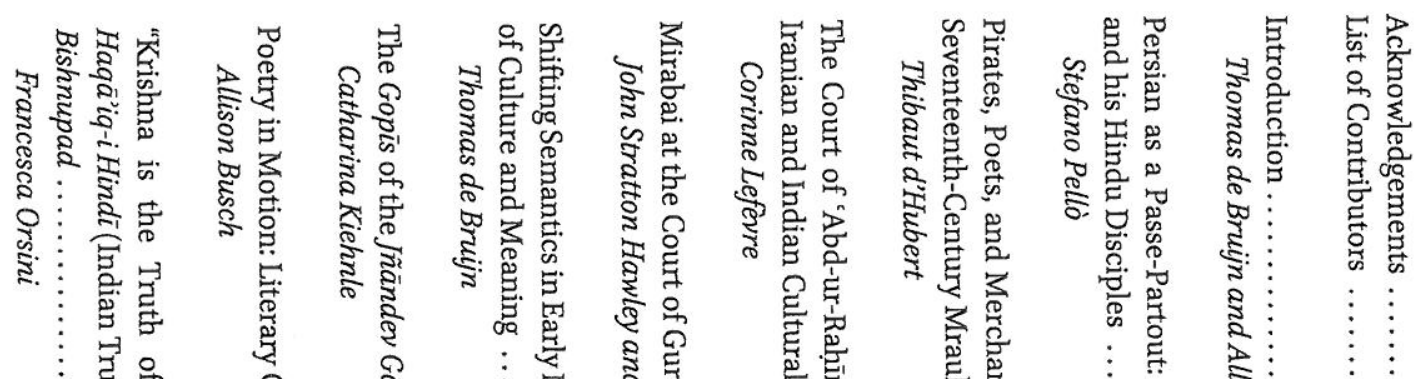

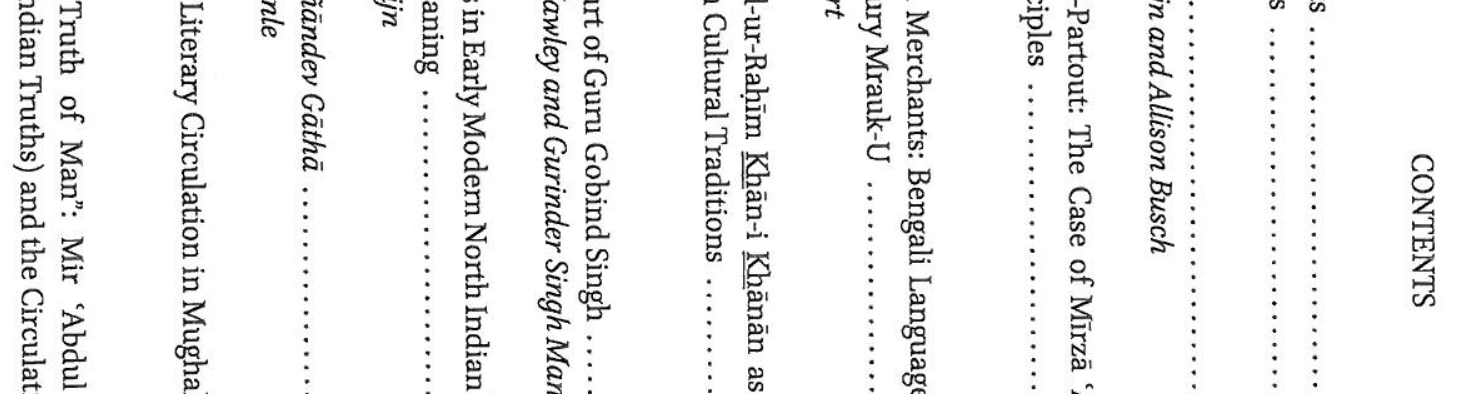

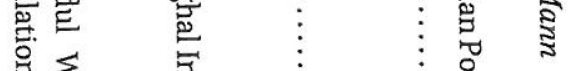

䓪芯

0 。

हूँ क्ष

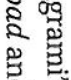

:

嗢 $\stackrel{5}{\circ}$

เั่

$\vdots$
$\vdots$
$\vdots$
$\vdots$
$\vdots$
$\vdots$
$\vdots$
$\vdots$
$\vdots$
$\vdots$
$\vdots$
$\vdots$
$\vdots$
$\vdots$
$\vdots$
0
0

f 


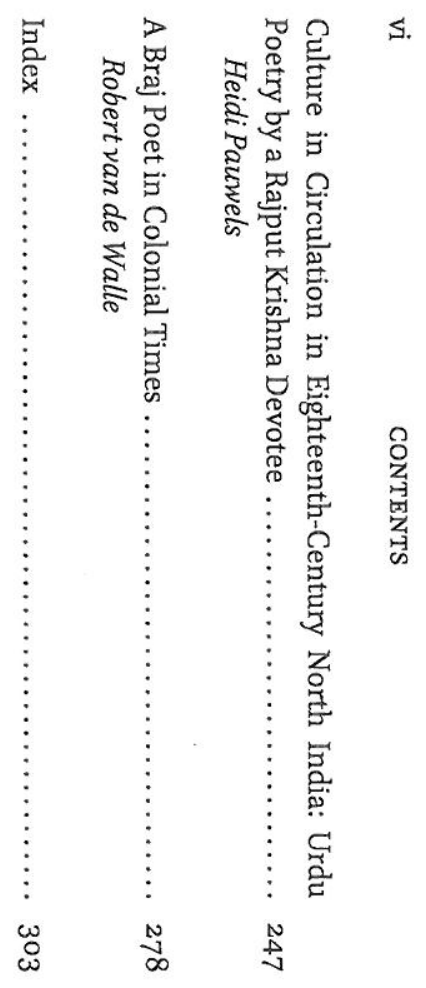

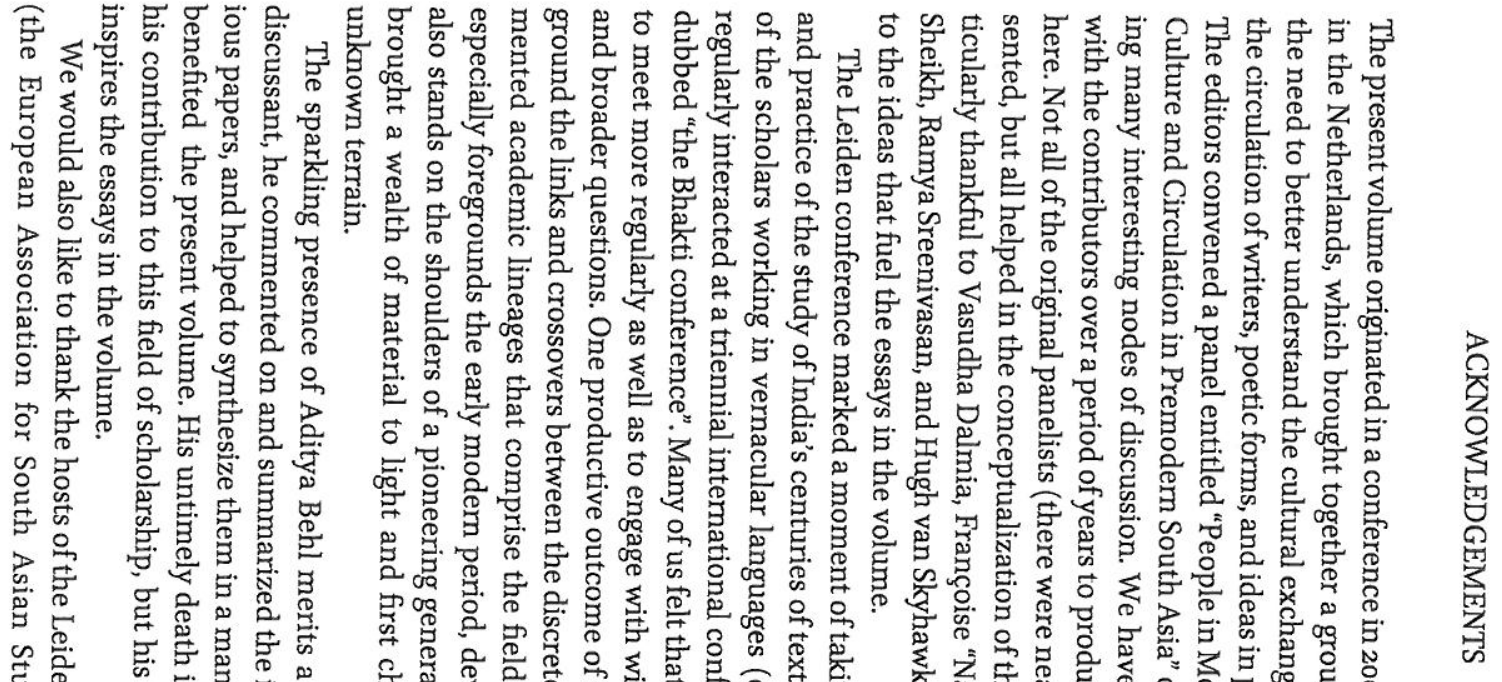

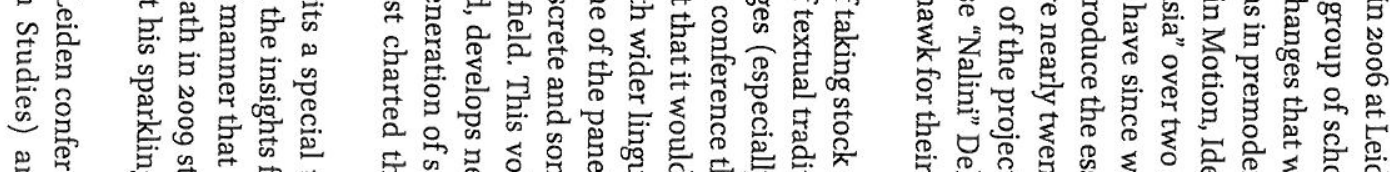

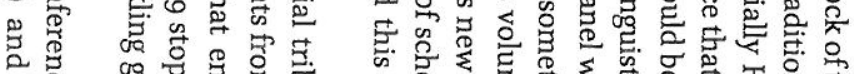

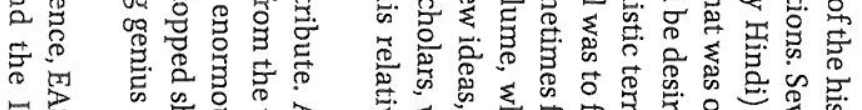

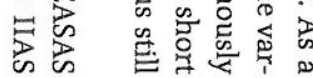

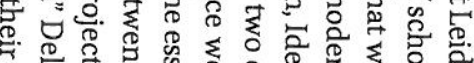

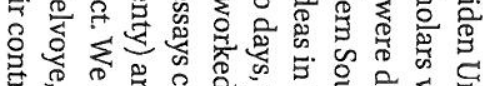

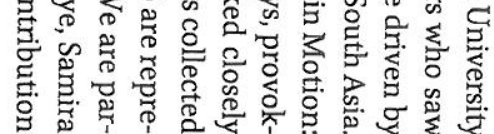

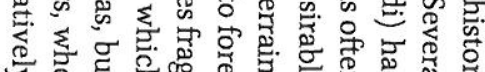




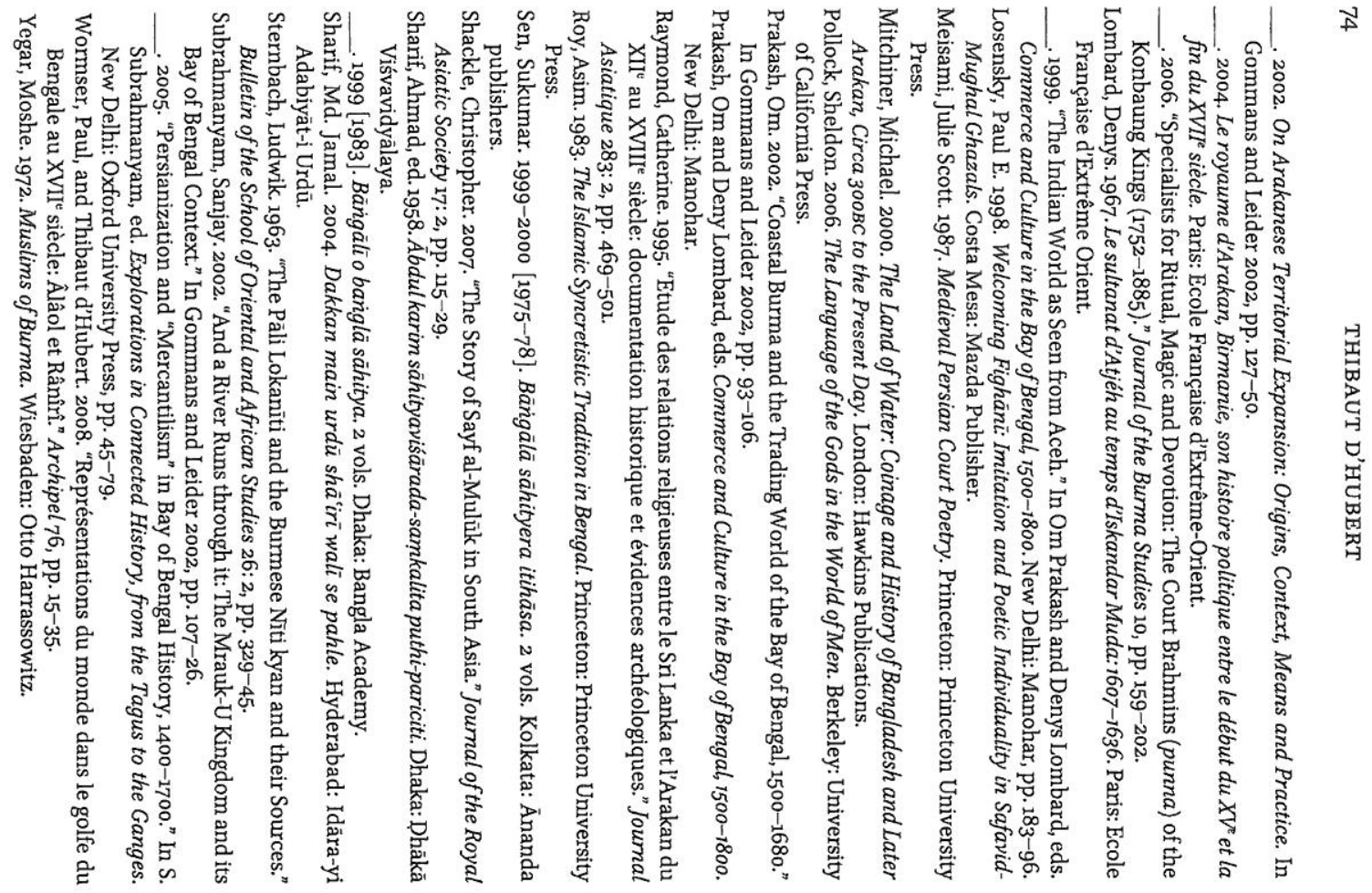

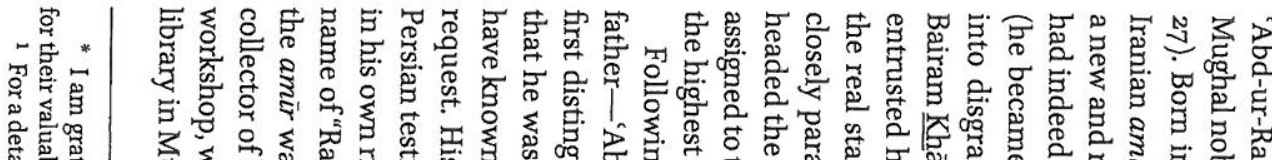

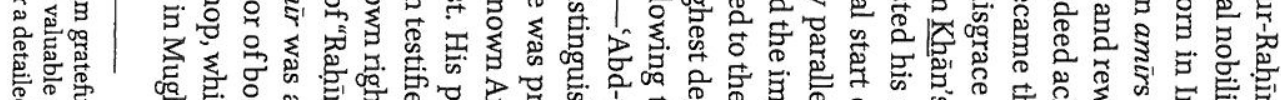

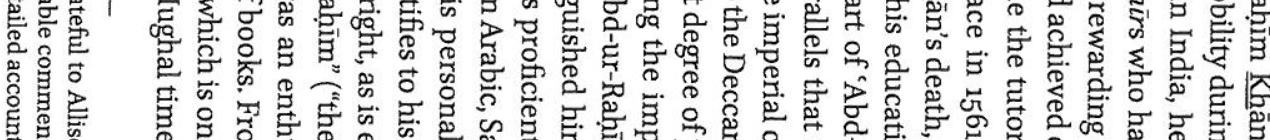

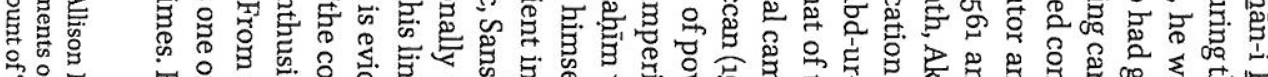

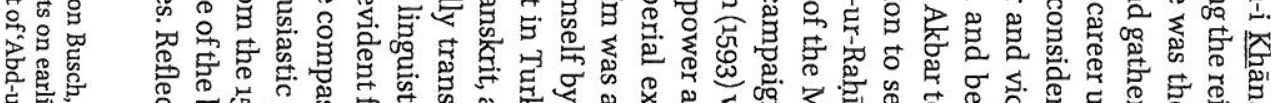

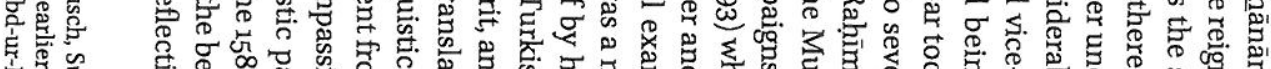

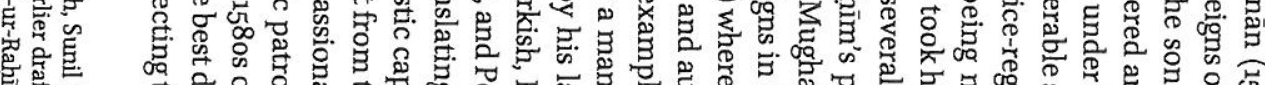

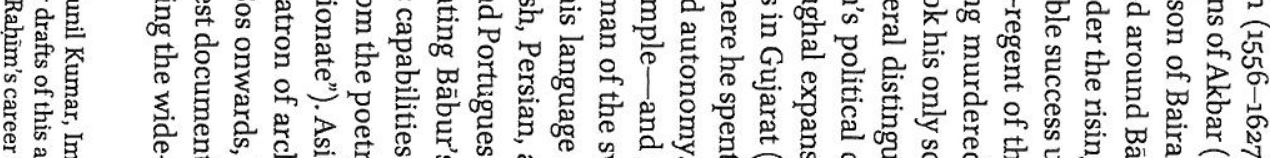

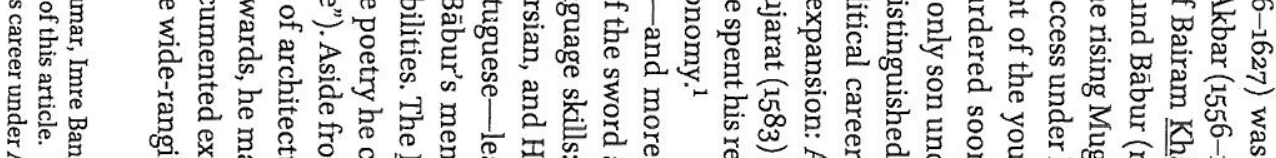

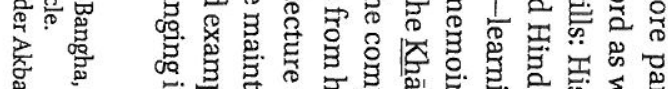

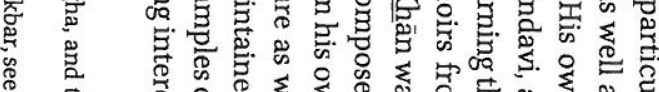

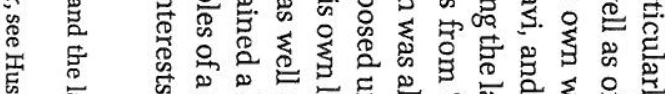

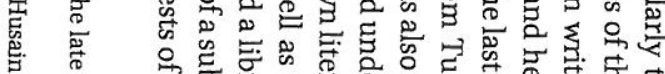

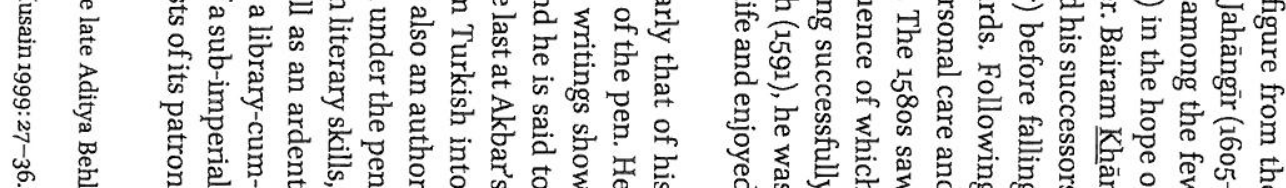

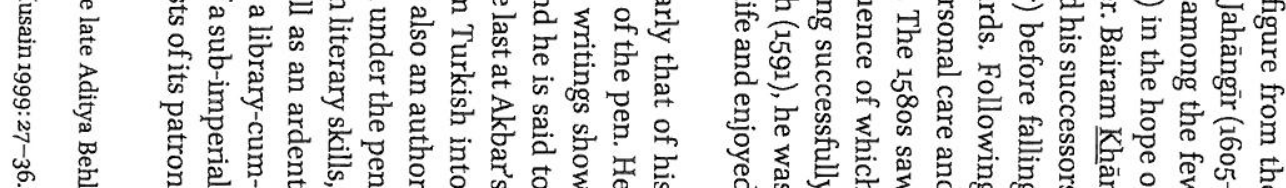

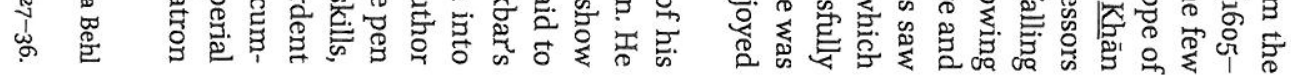

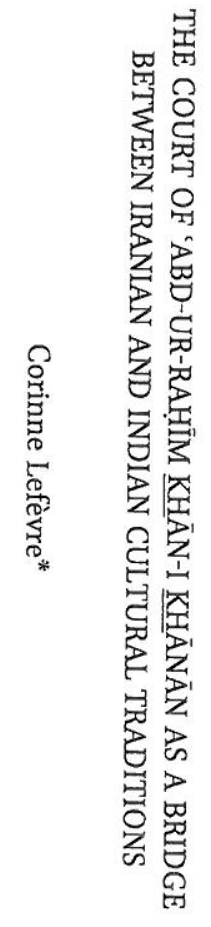




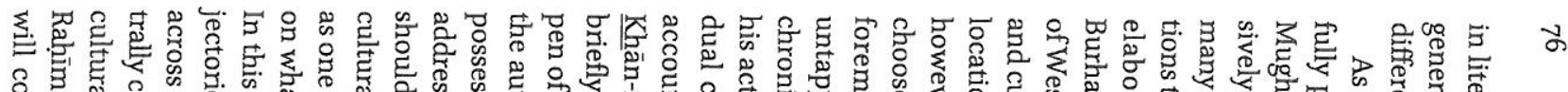
8

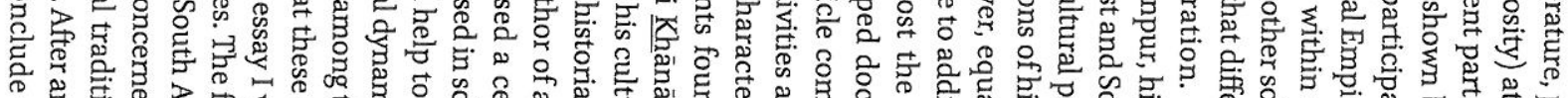

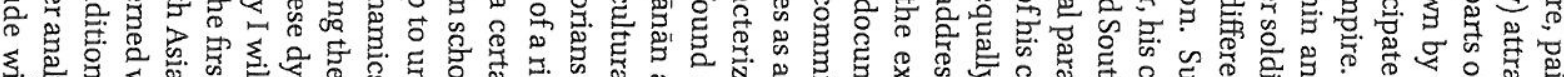

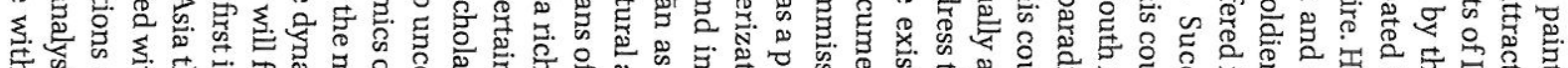

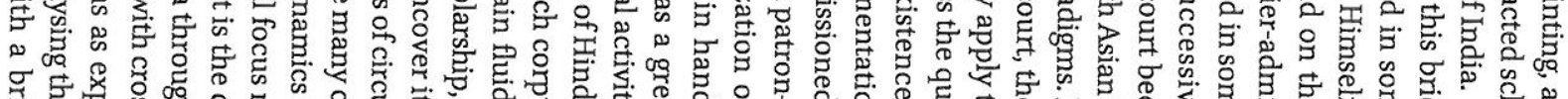

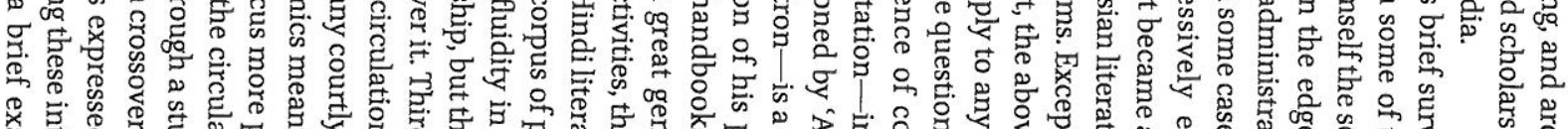

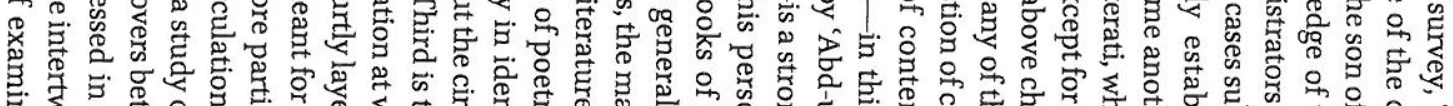

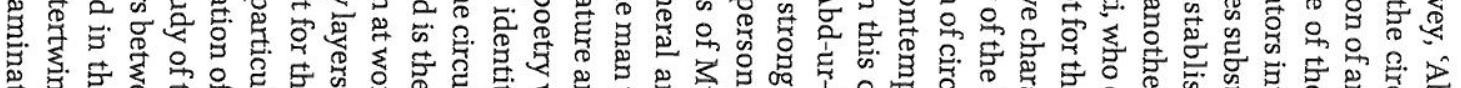

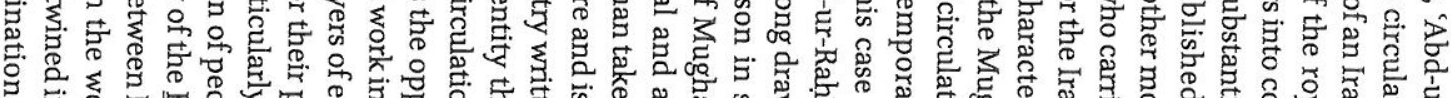

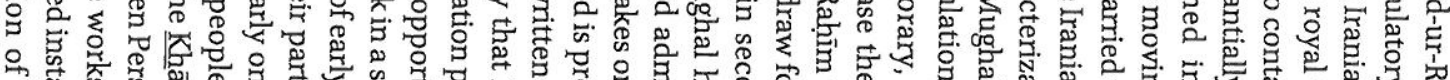

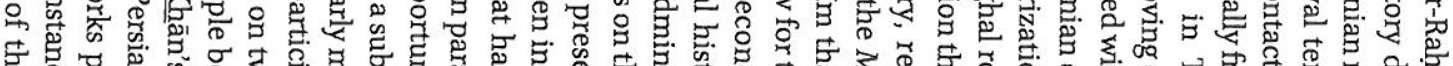

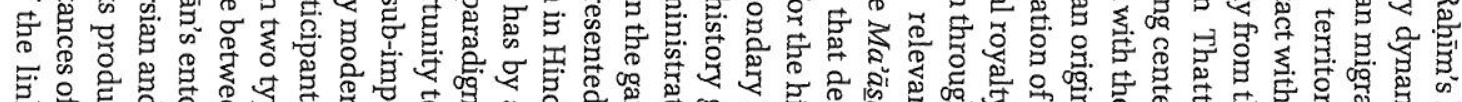

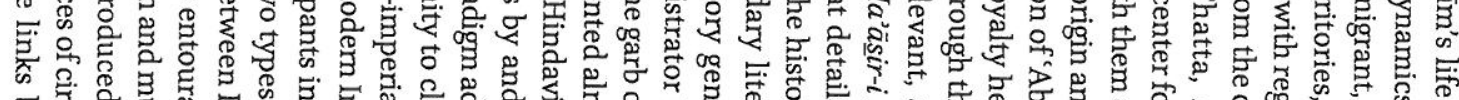

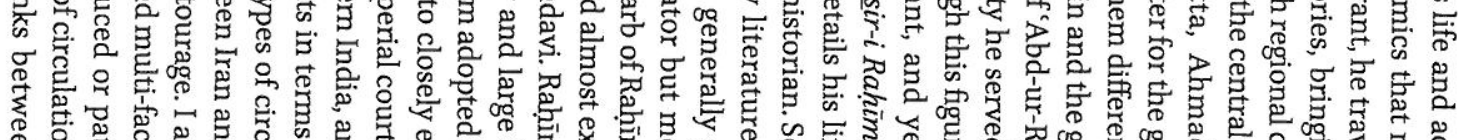

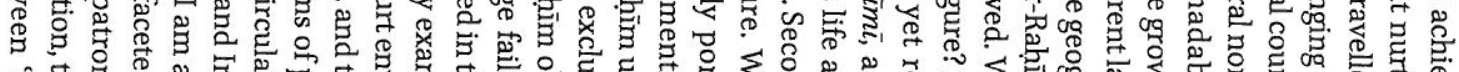

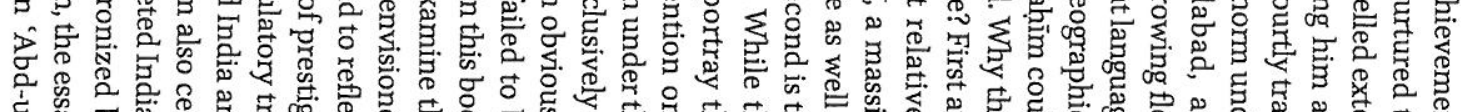

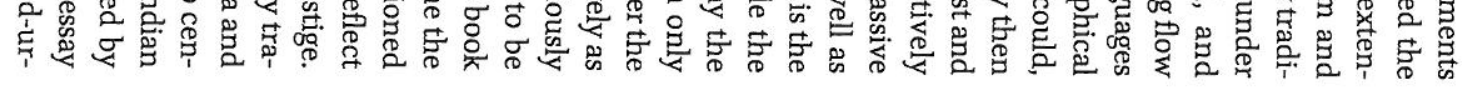

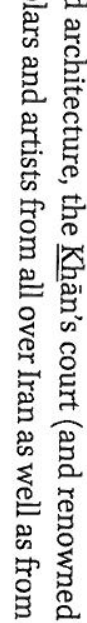

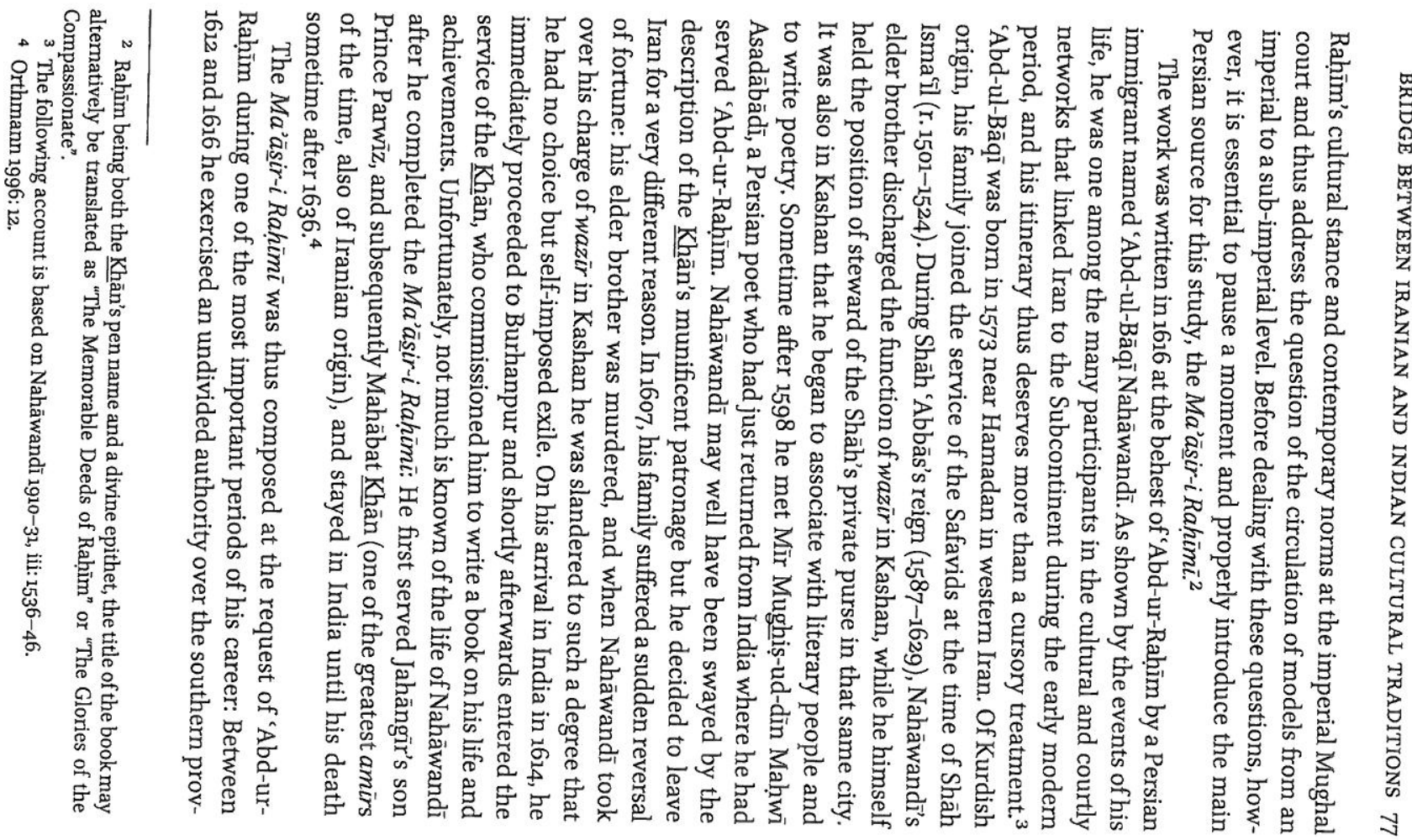



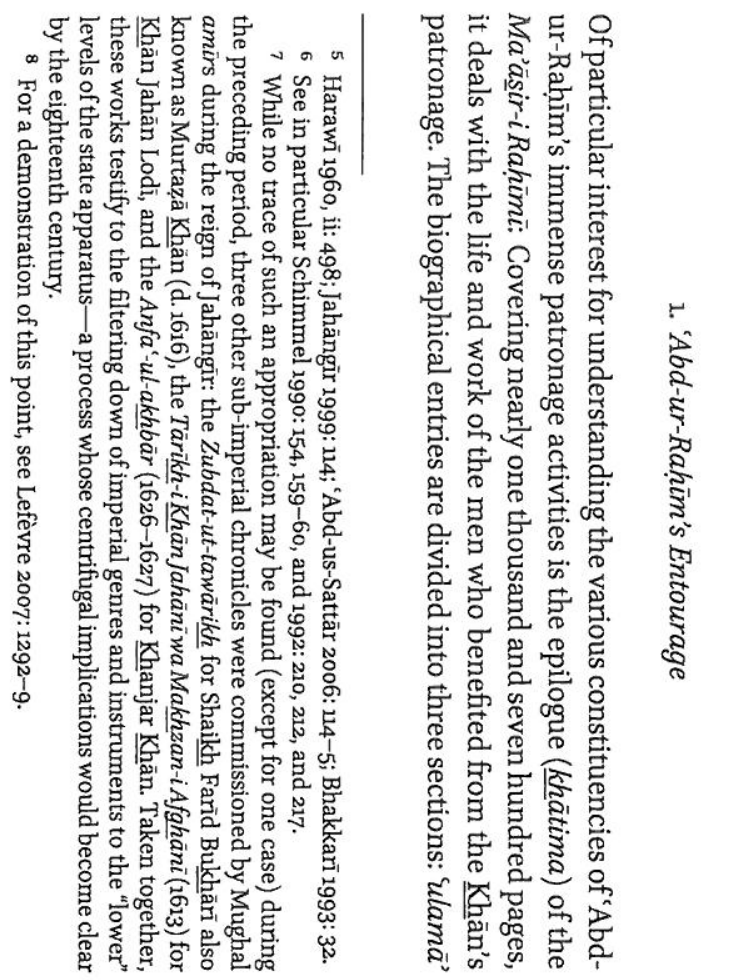

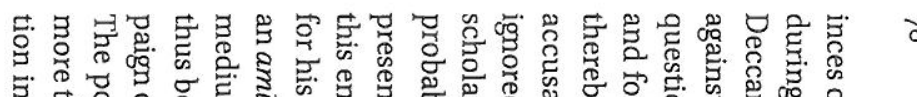
$\infty$

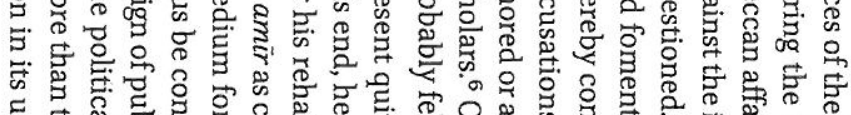

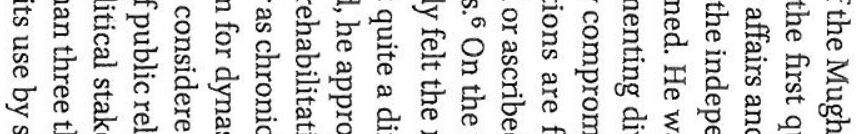

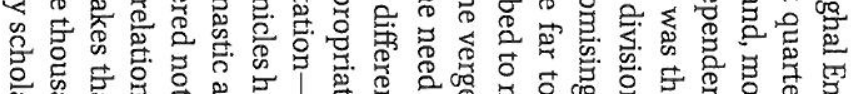

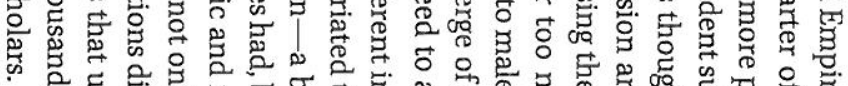

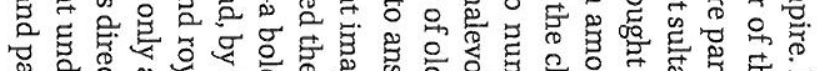

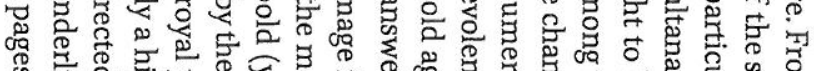

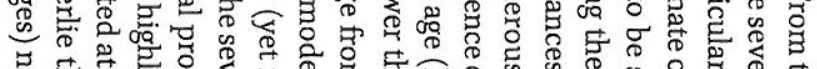

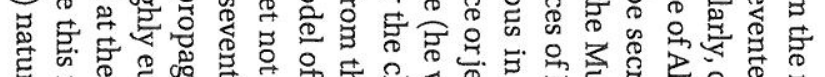

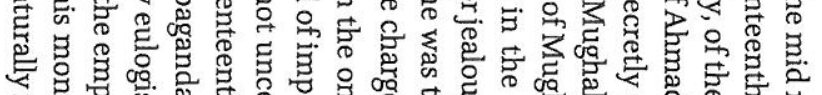

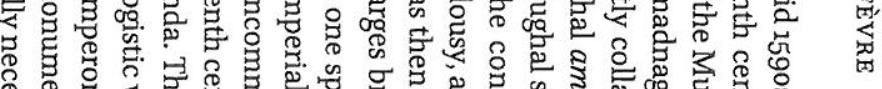

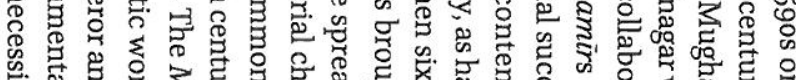

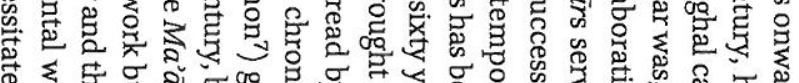

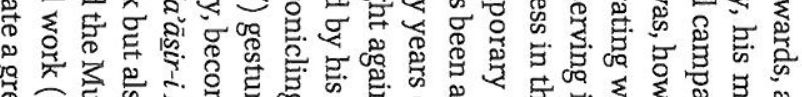

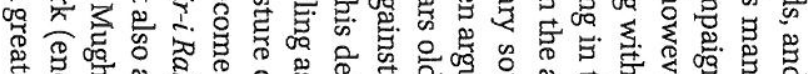

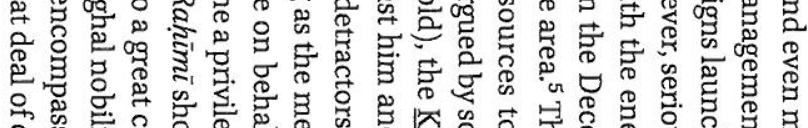

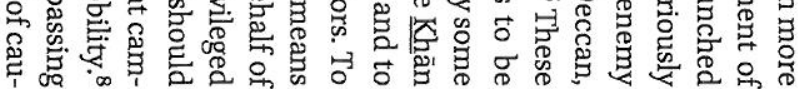

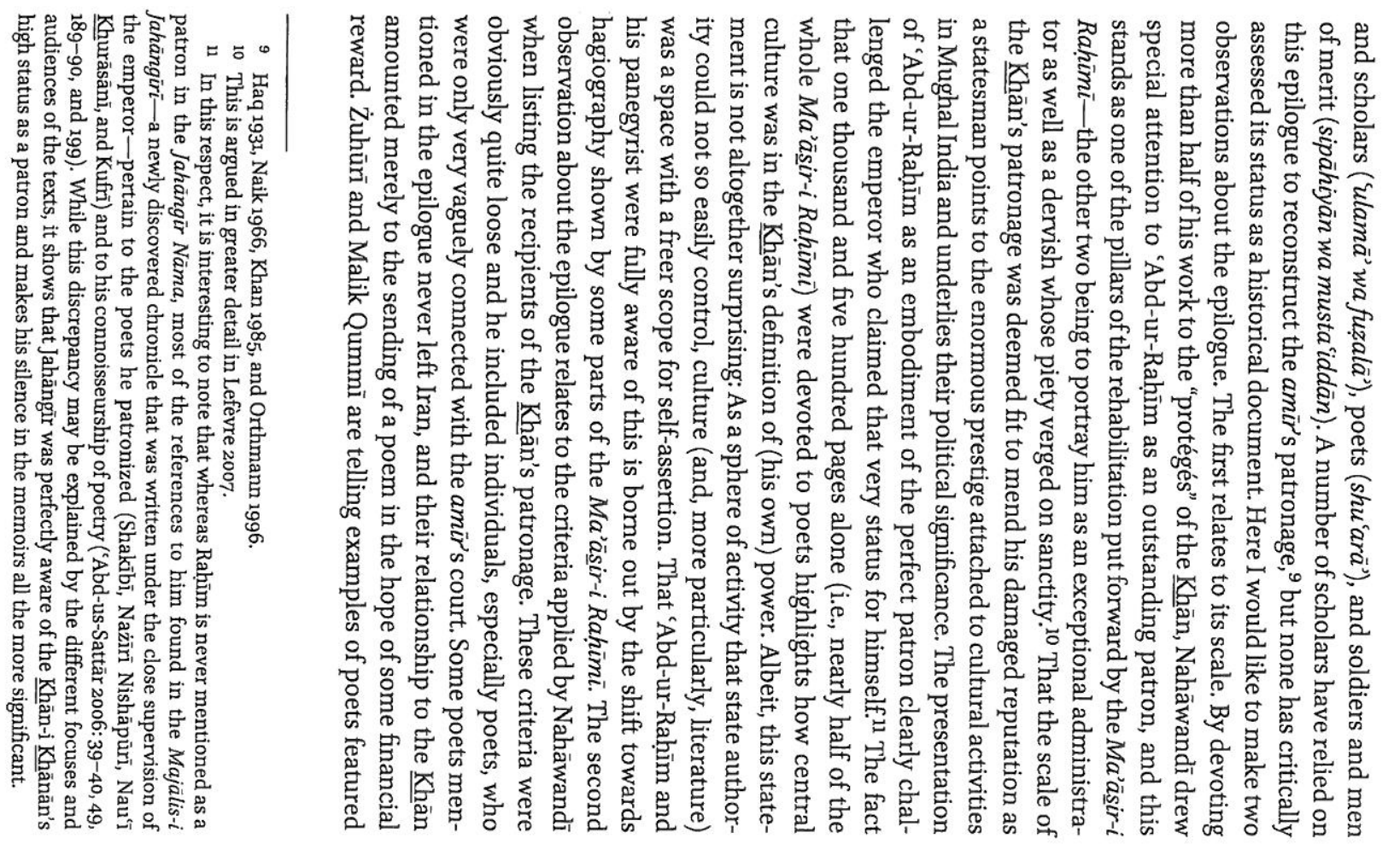




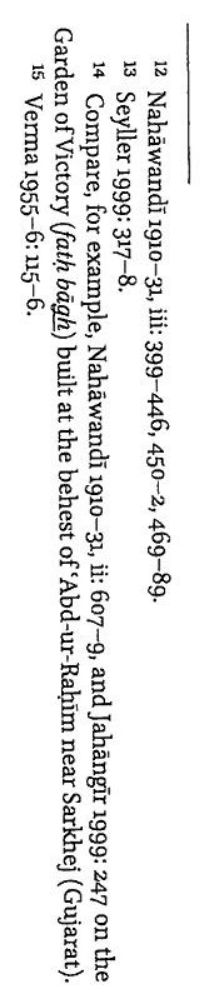

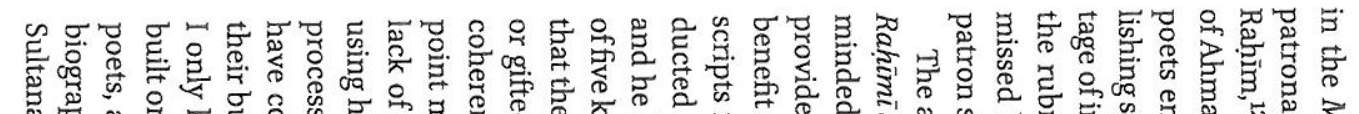
$\infty$

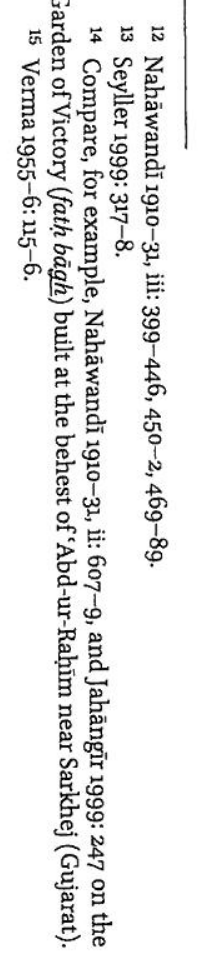

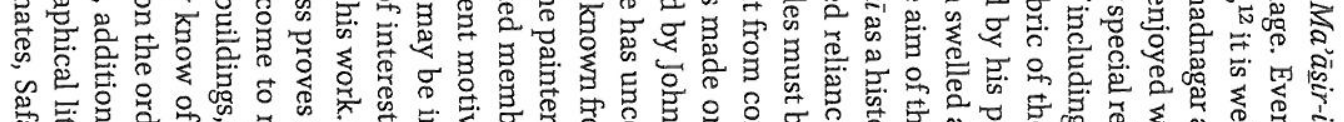

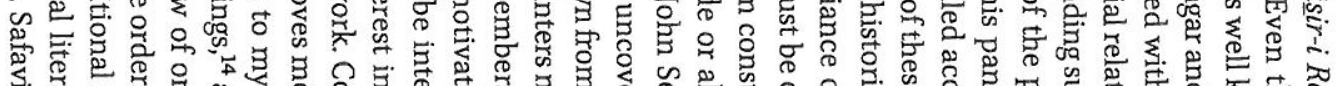

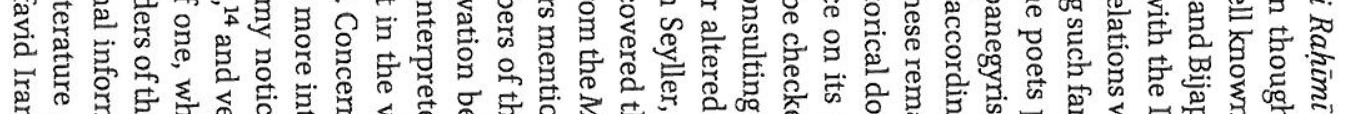

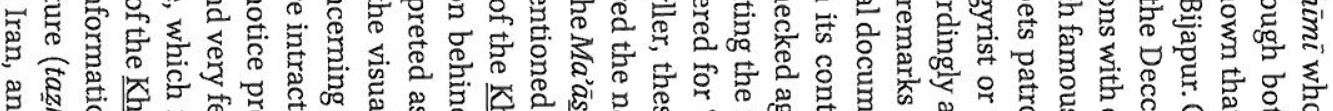

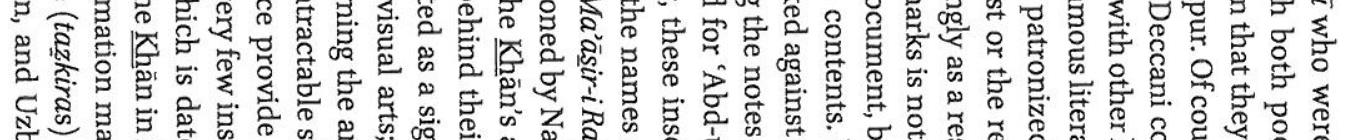

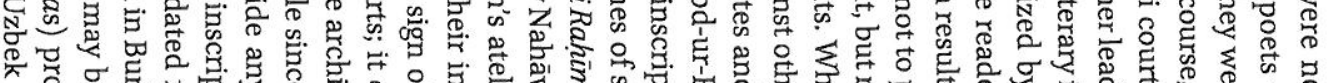

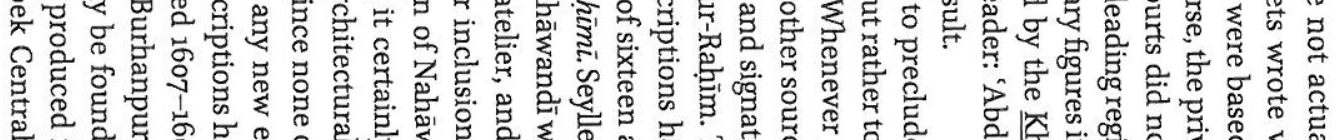

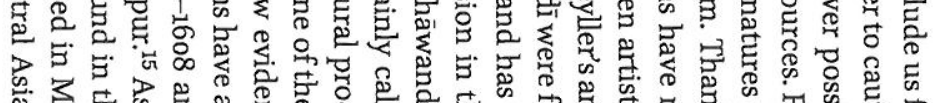

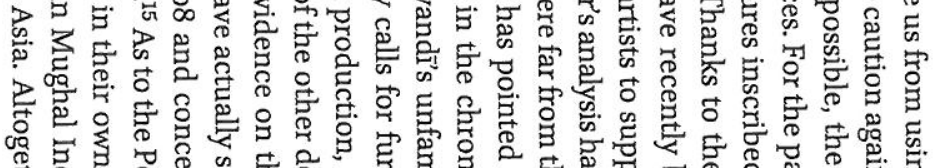

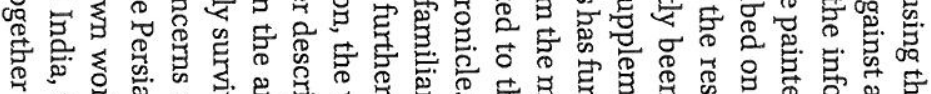

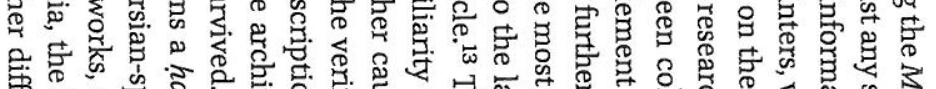

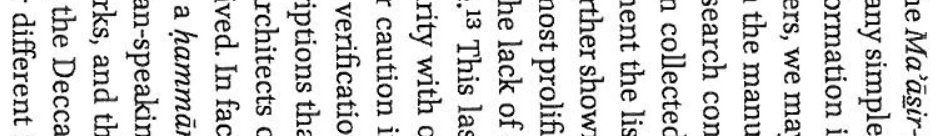

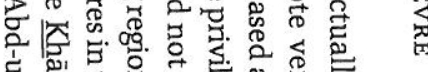

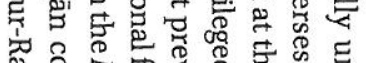

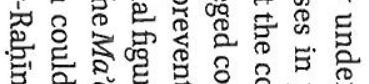

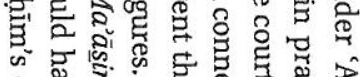

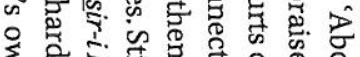

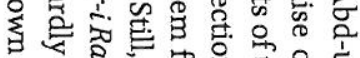

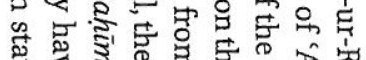

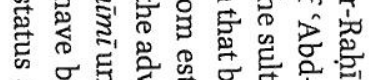

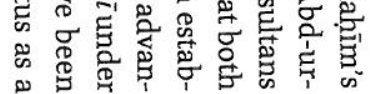




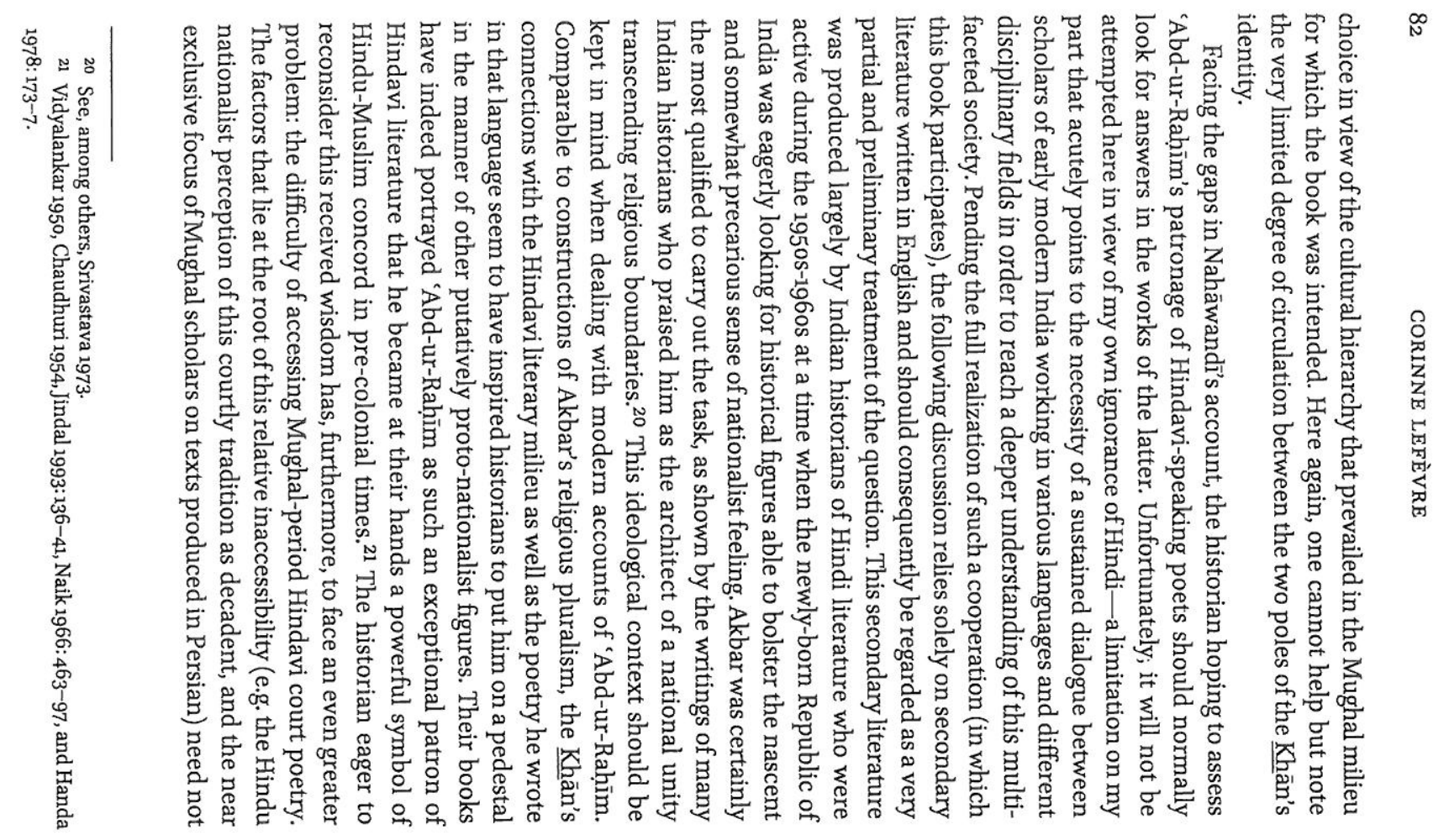

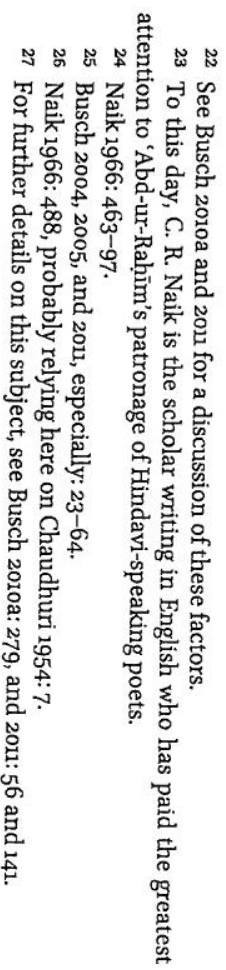

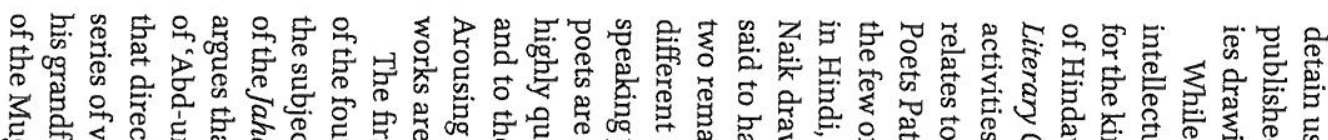

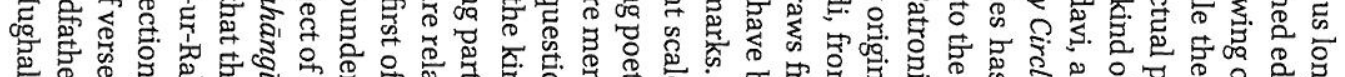

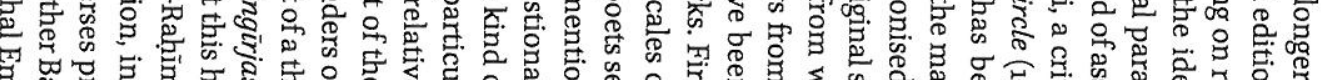

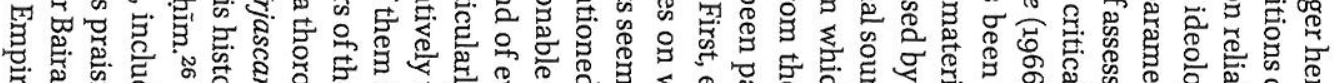

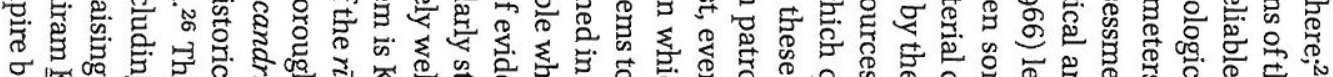

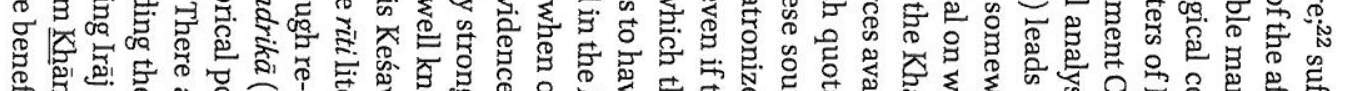

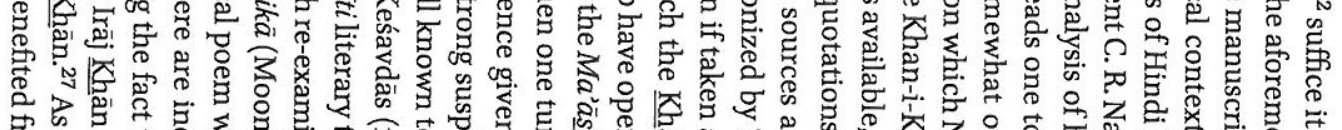

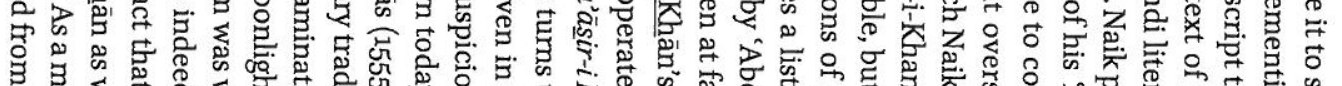

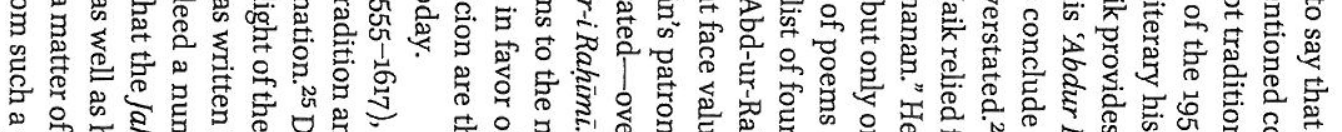

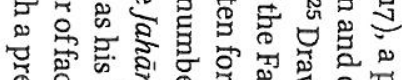

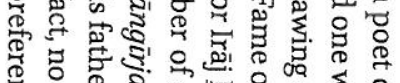

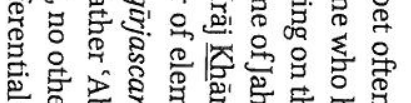

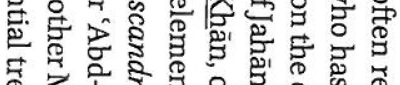

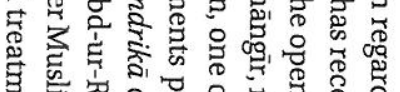

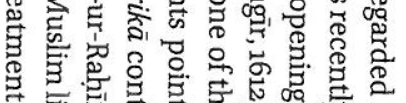

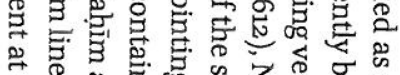

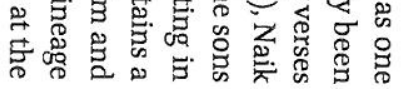

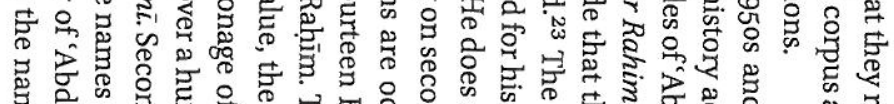

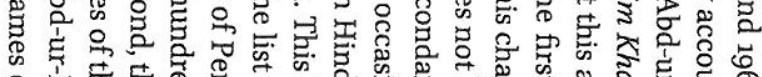

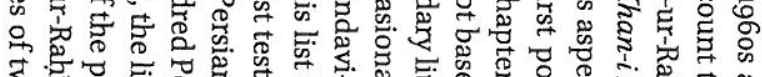

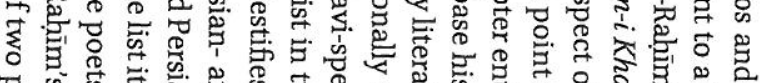
等

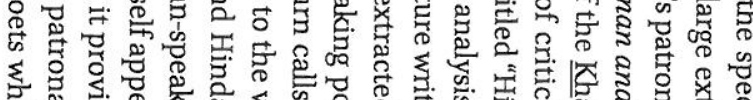

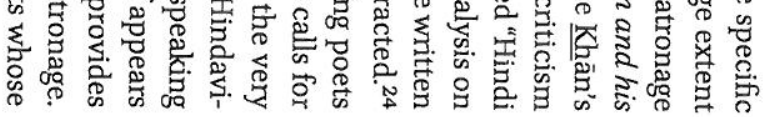

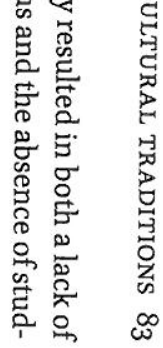




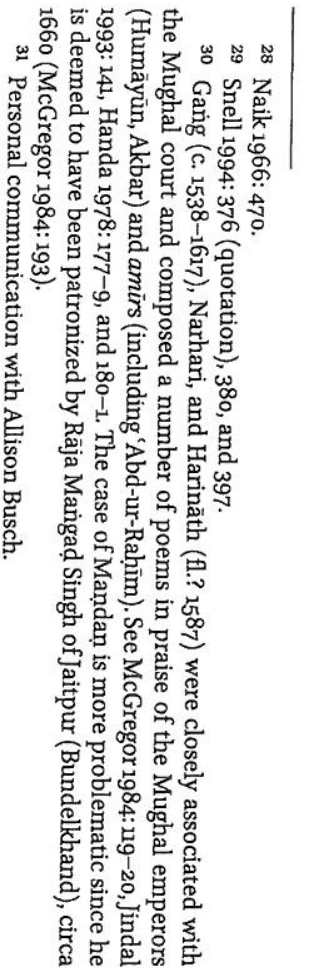

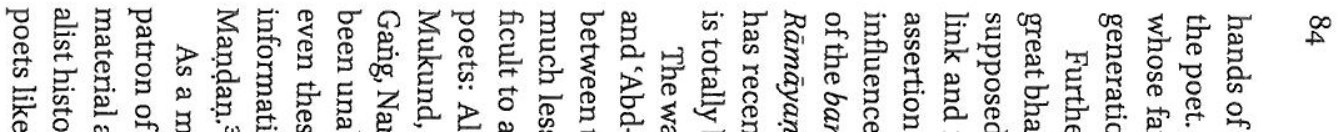

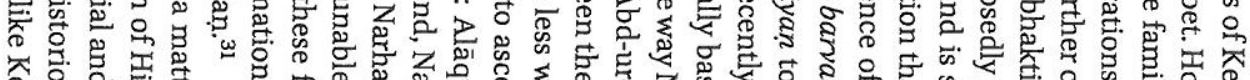

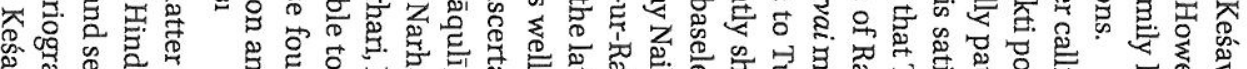

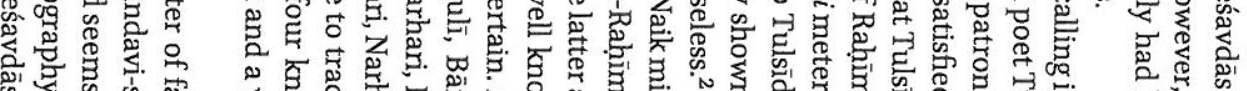

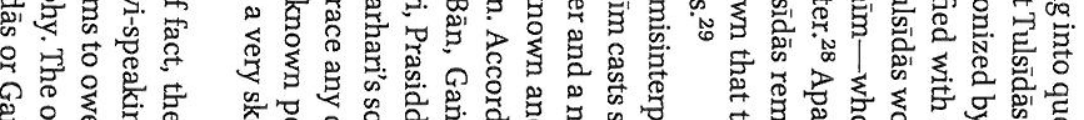

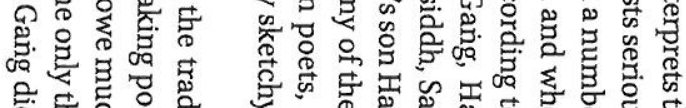

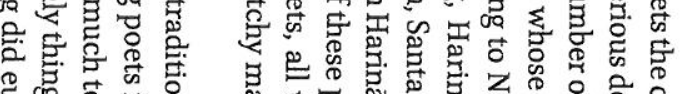
范蕰

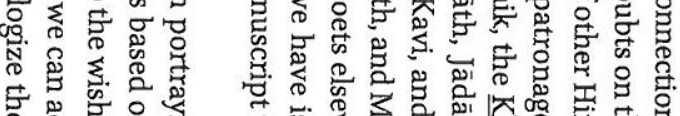

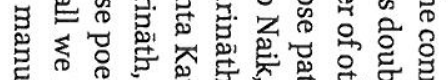

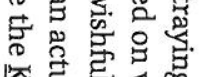

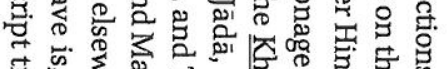

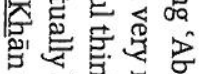

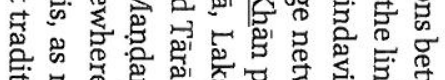

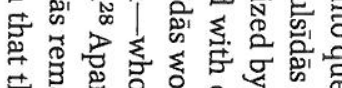

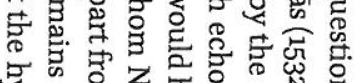

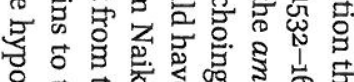

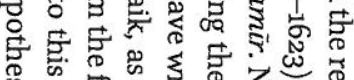

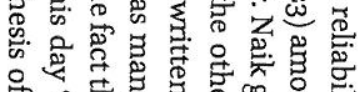

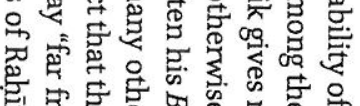

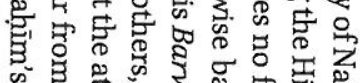
心

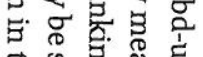

두유.

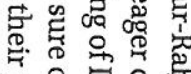
总总家兽

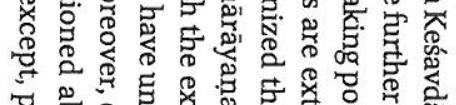

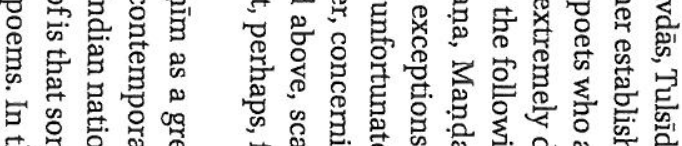

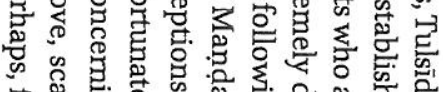

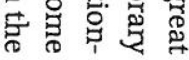

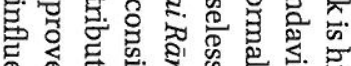

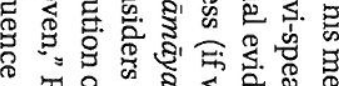

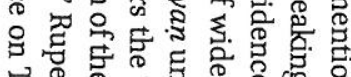

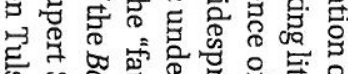

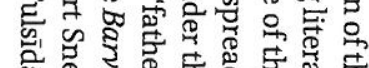

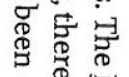

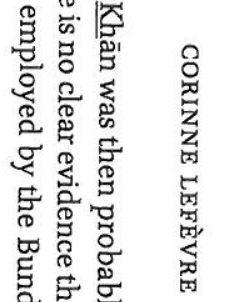
空志 兽官

品要

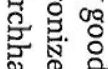
实声泀

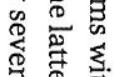

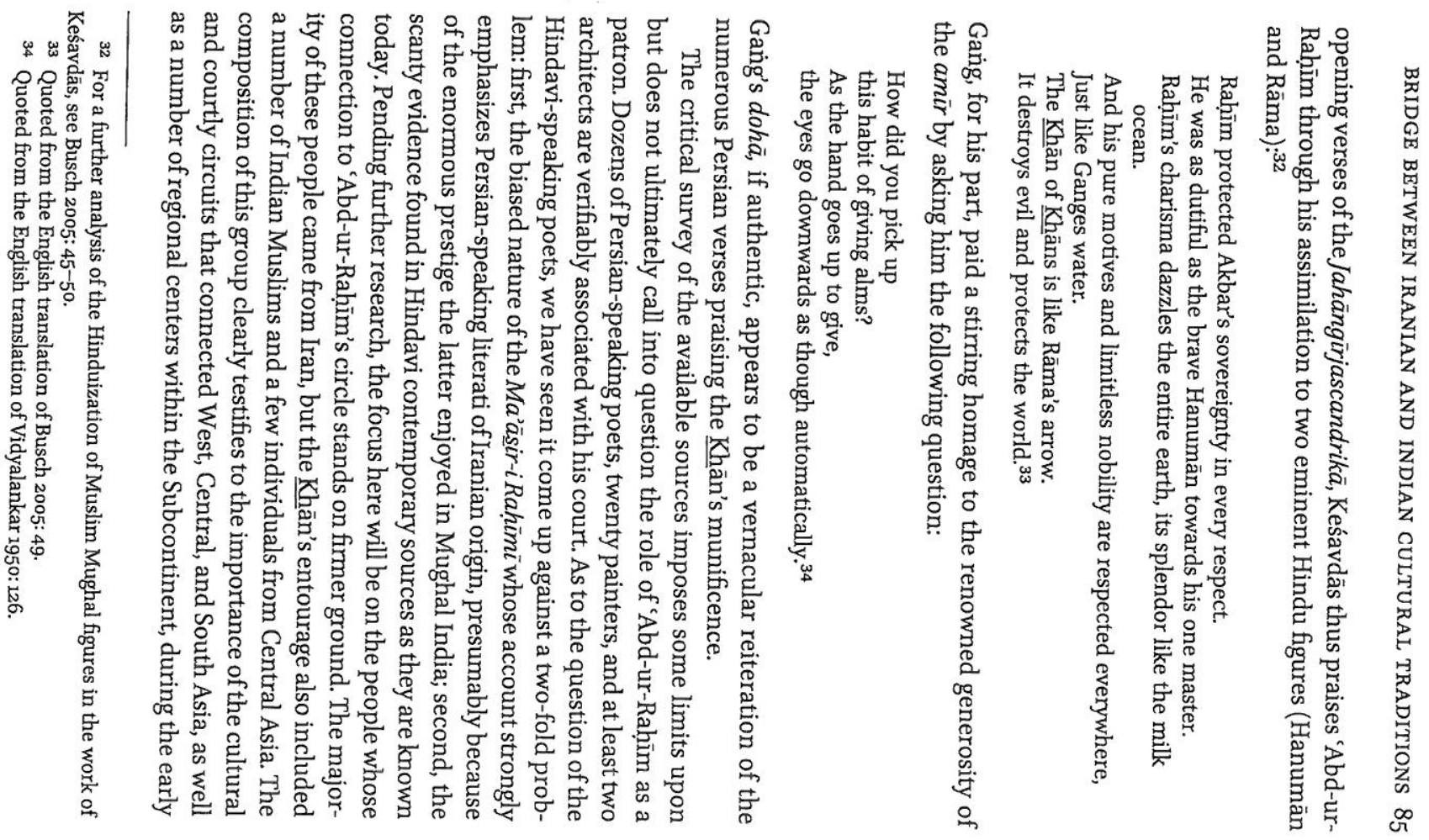




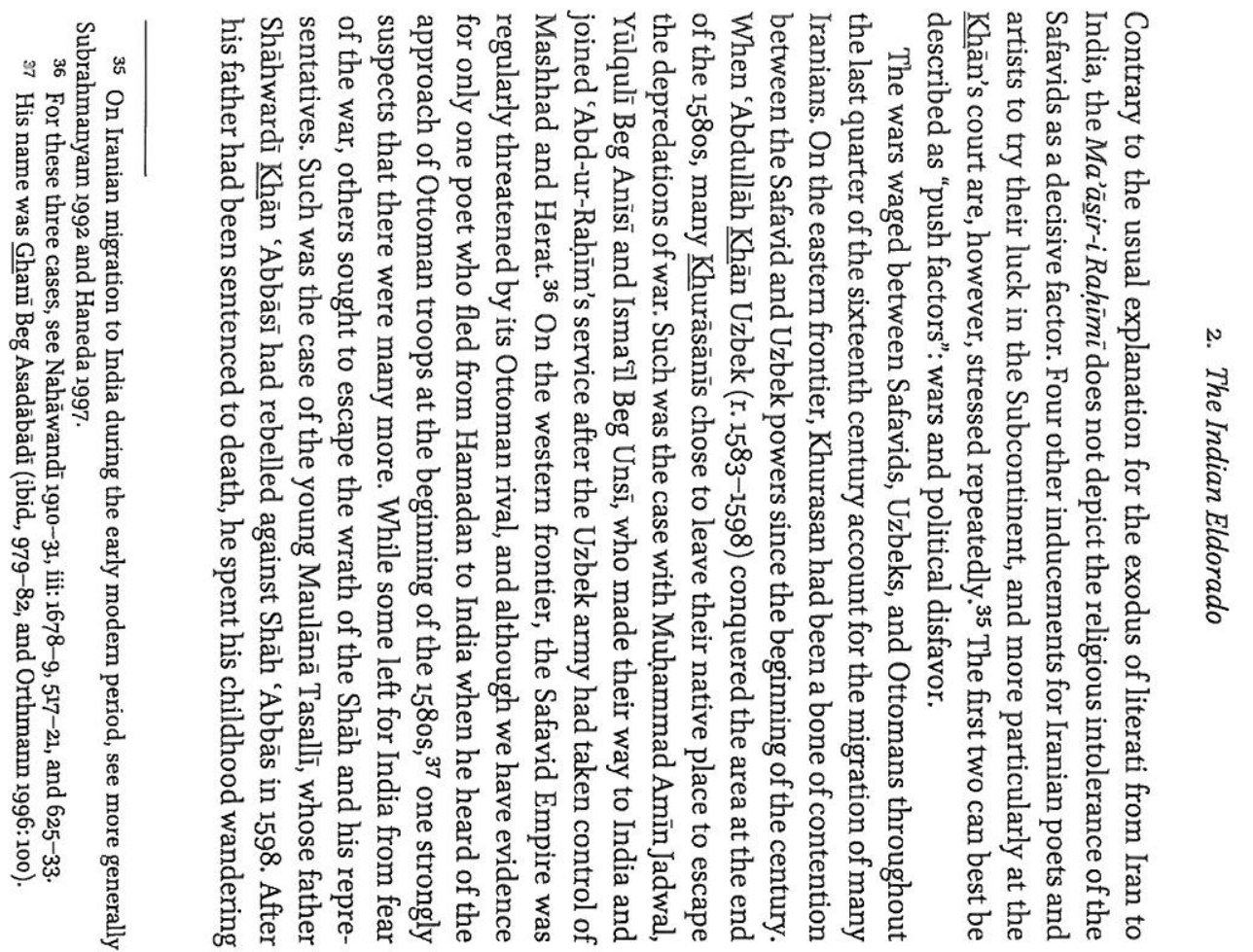

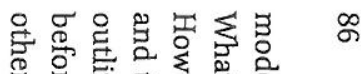

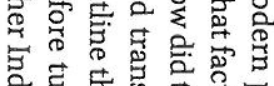

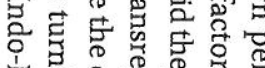

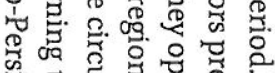

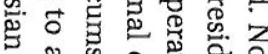
ช。

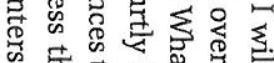

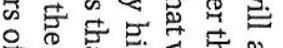
웡

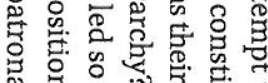

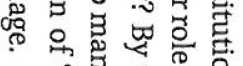

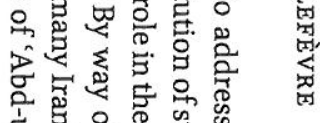

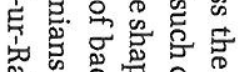

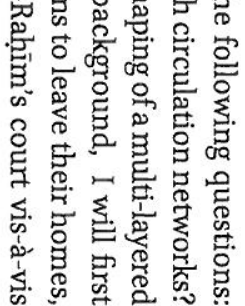

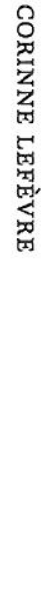

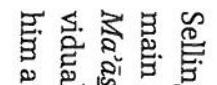

ㅇ \&

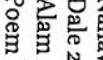
ఫ 范商

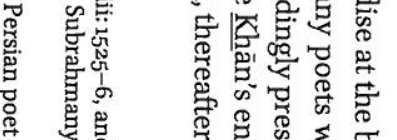

贻

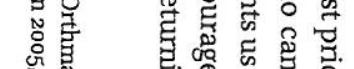$$
\text { 萬兽 }
$$

:

$\ddot{\oplus}$
I.

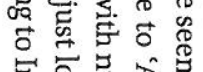

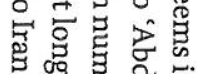

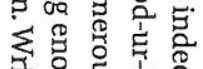

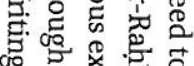

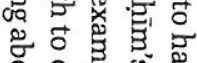

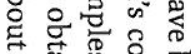

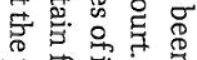

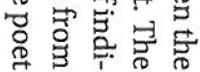

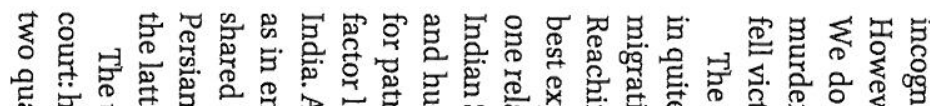

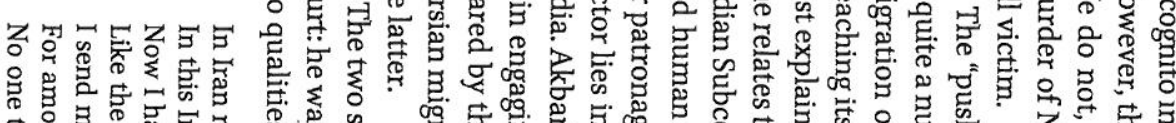

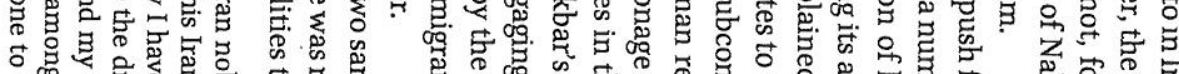

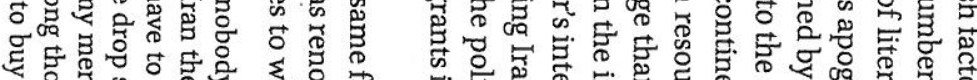

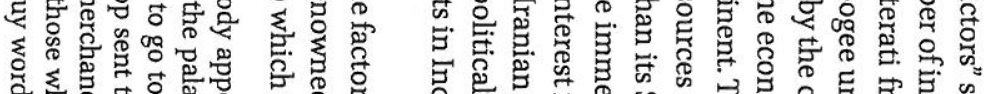

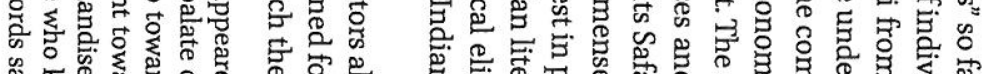

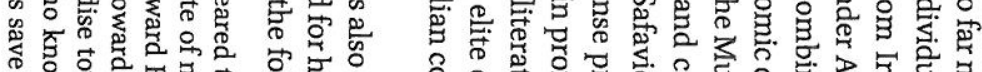

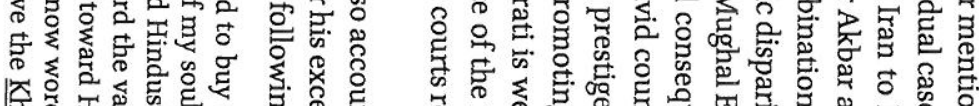

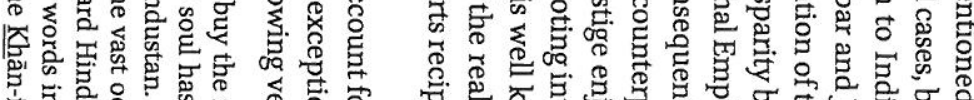

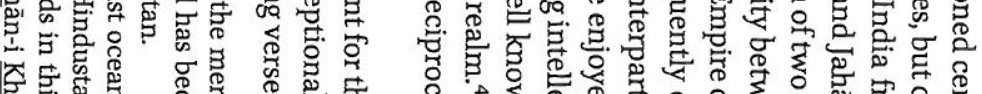

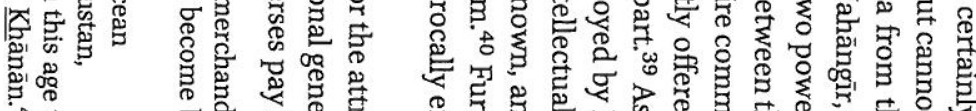

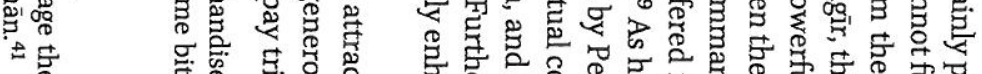

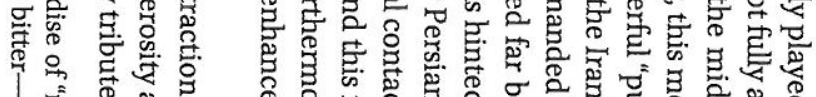
矢

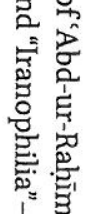

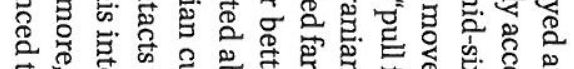

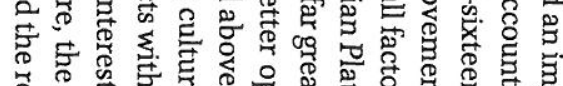

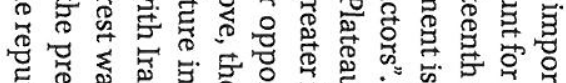

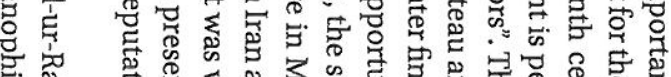

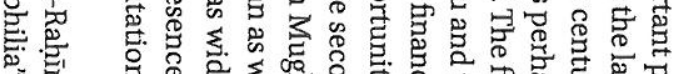

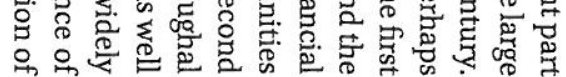

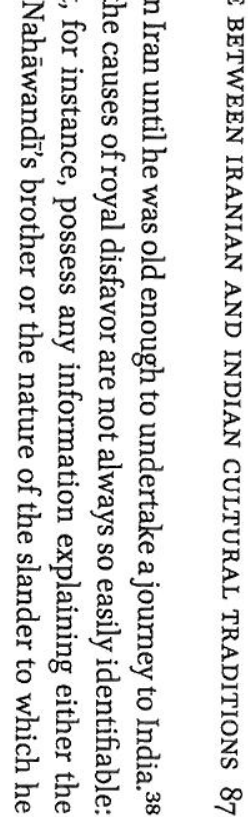




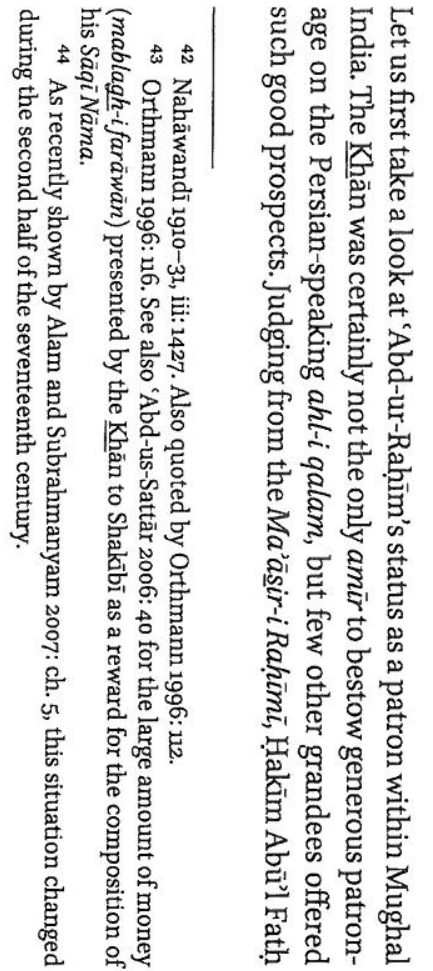

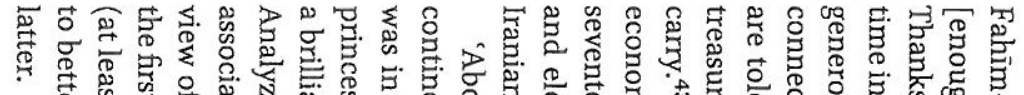

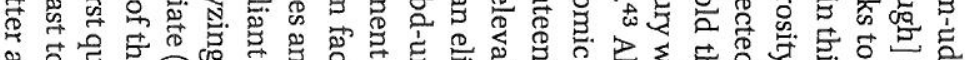

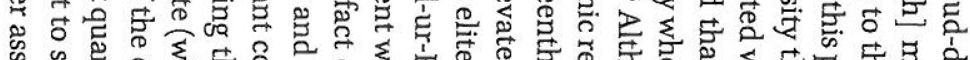

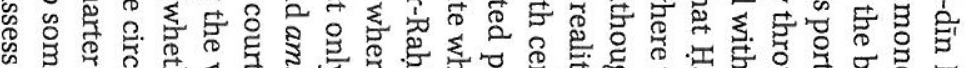

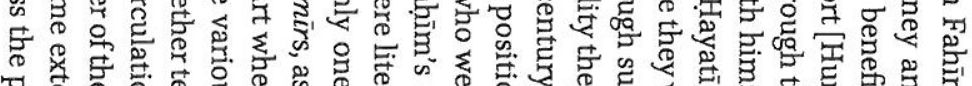

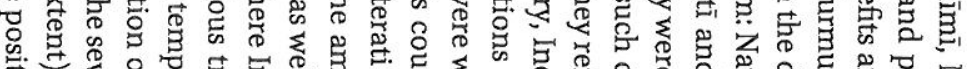

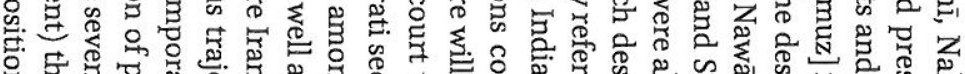

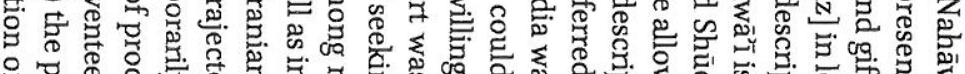
유유.

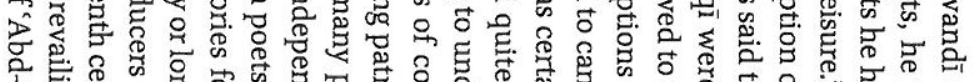

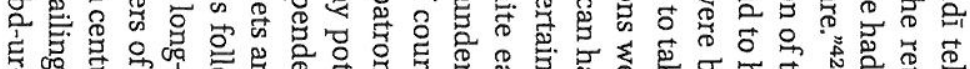

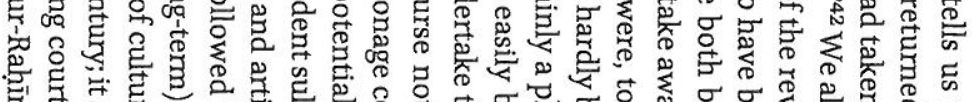

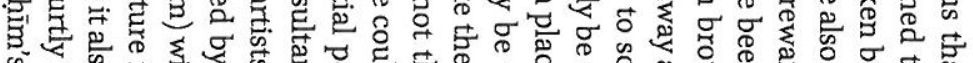

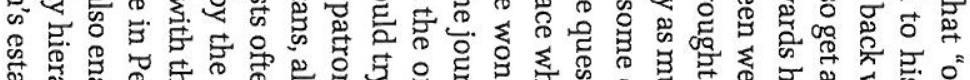

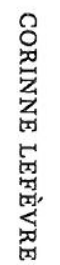

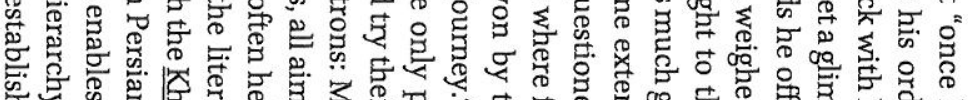

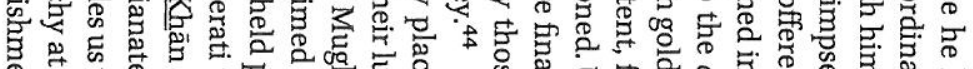

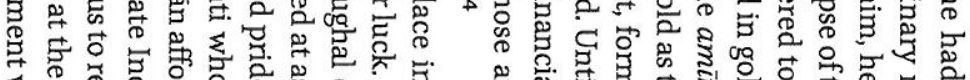

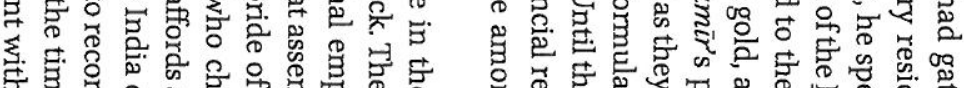

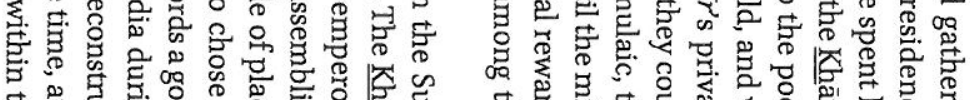

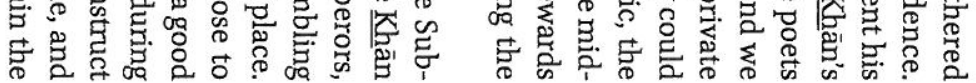

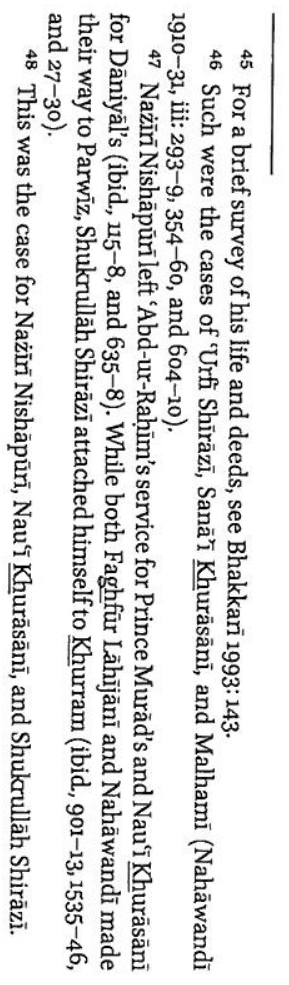

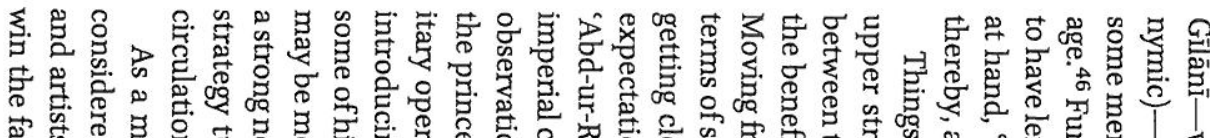

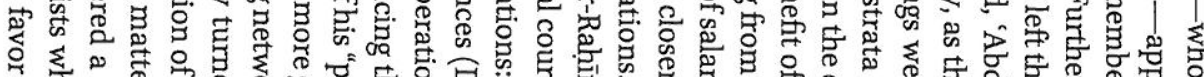

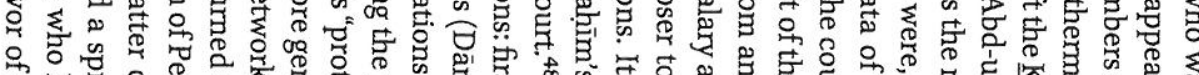

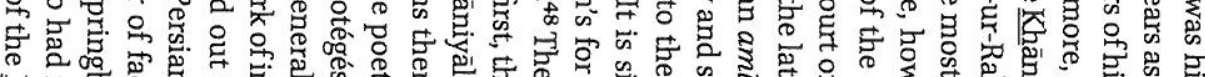

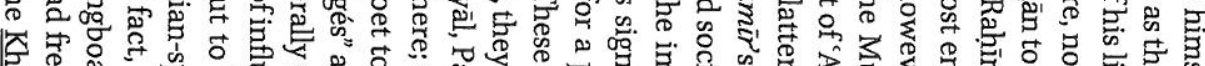

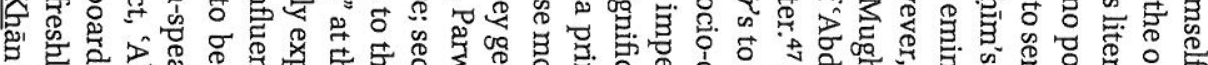
ज.

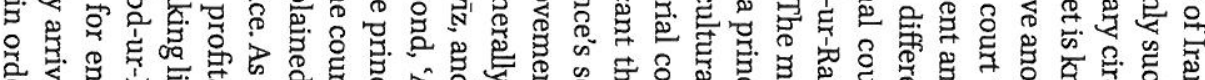

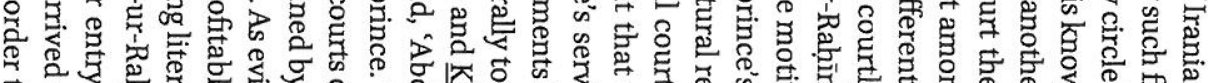

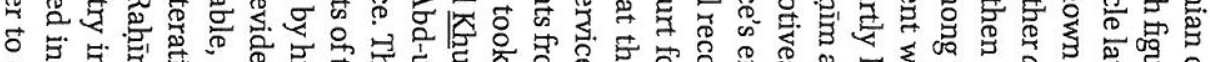

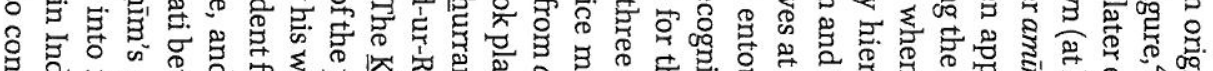

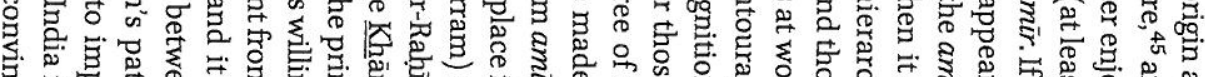

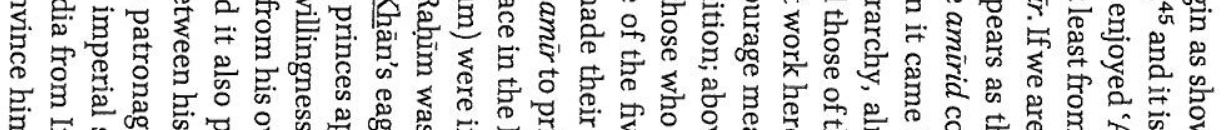

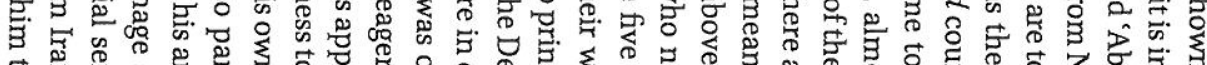

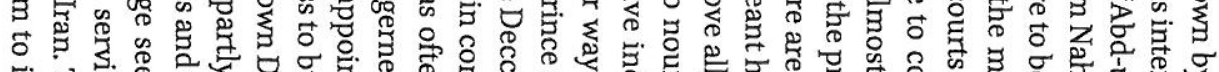

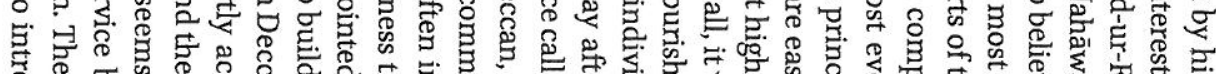

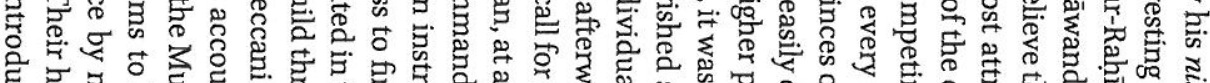

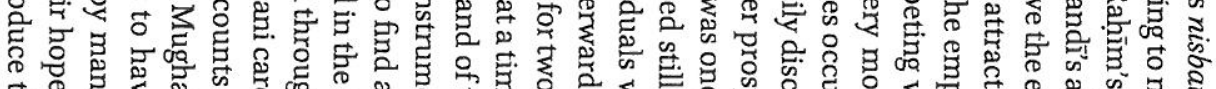

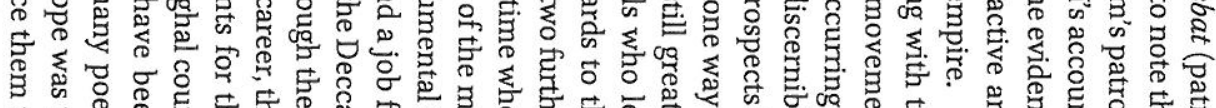

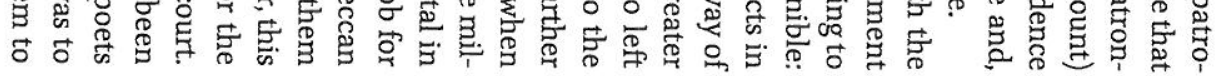




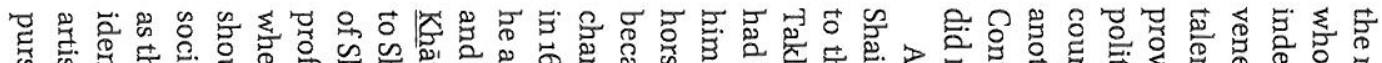

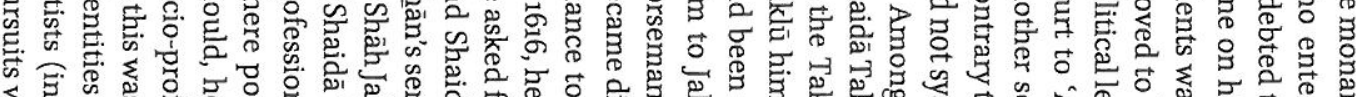

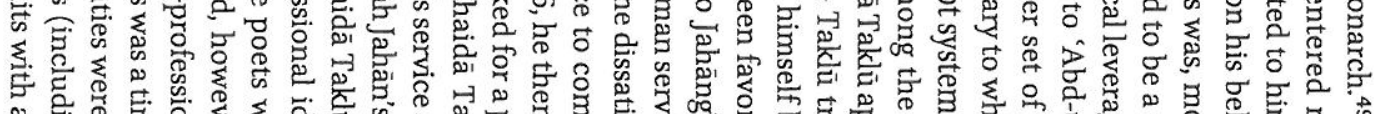

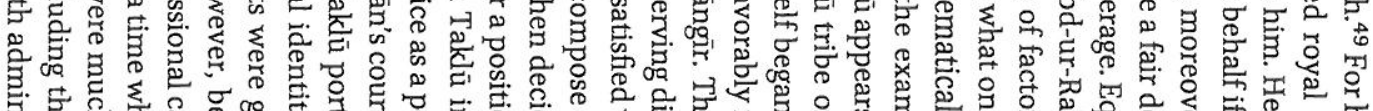

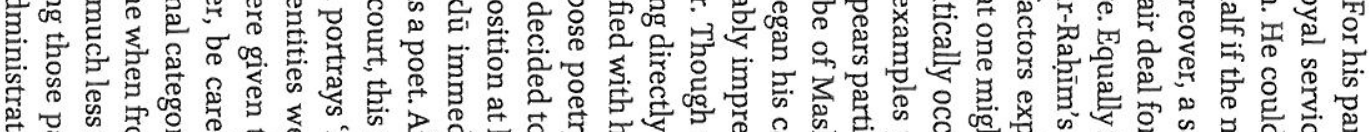
等

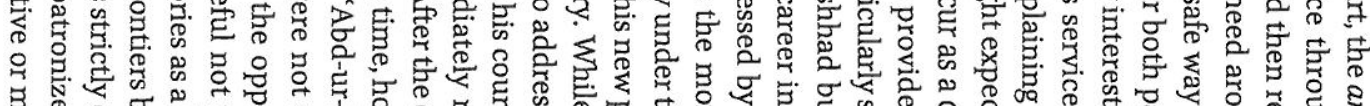

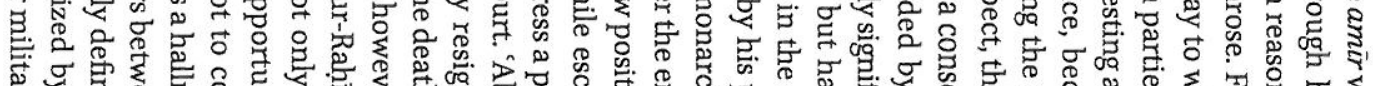

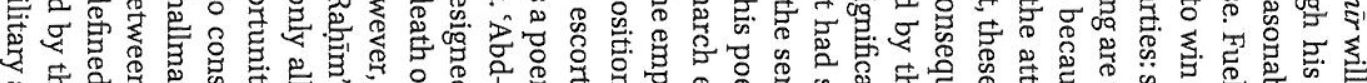

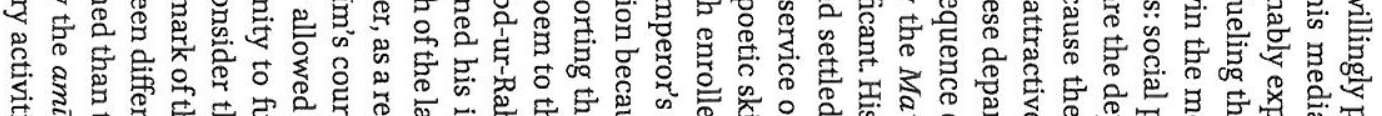

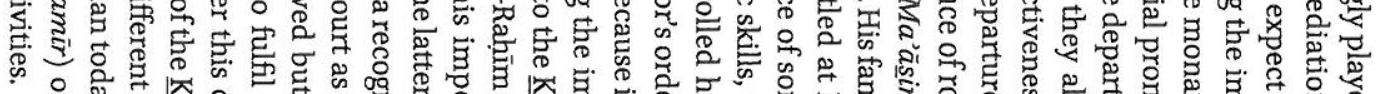

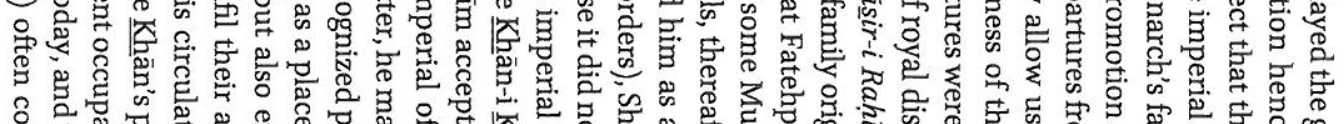

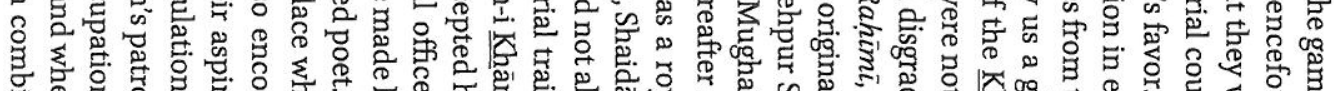

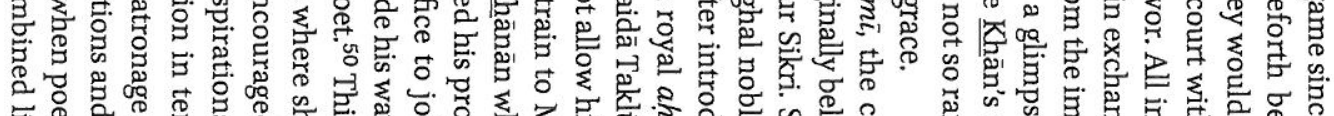

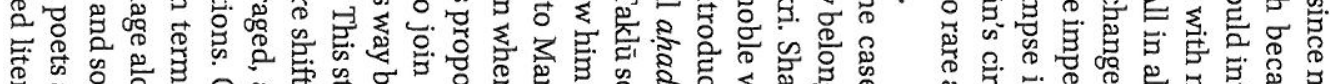

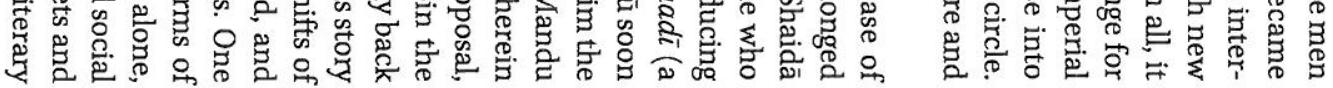




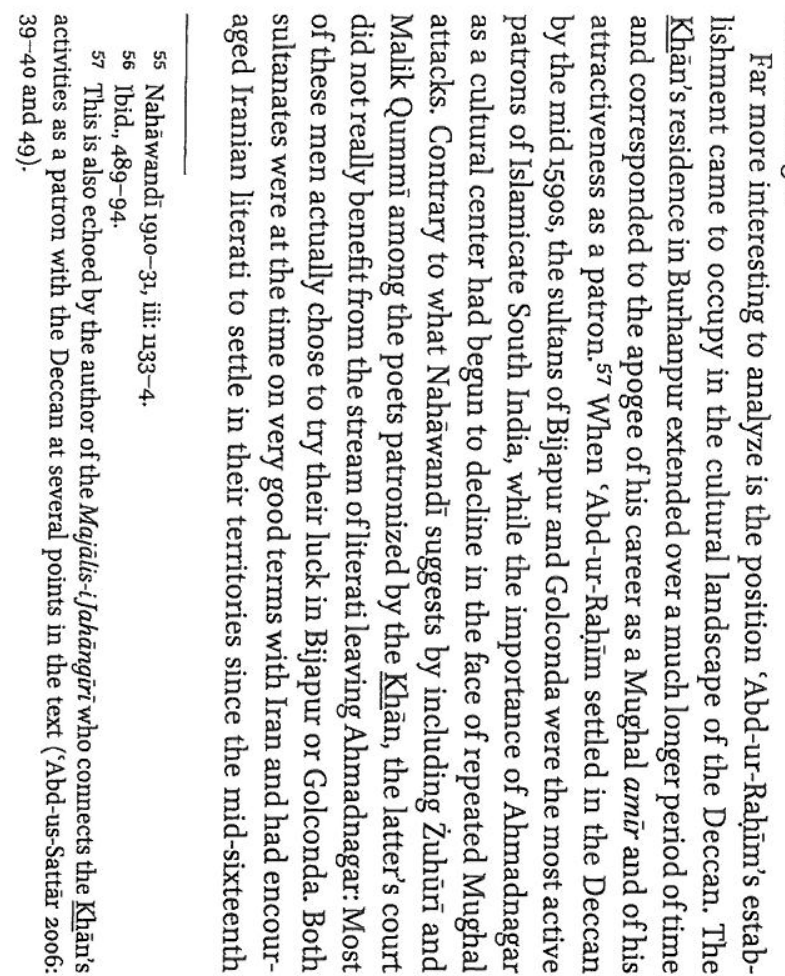

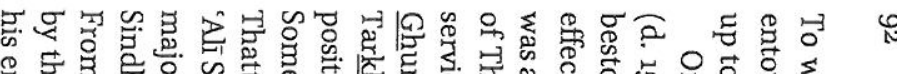

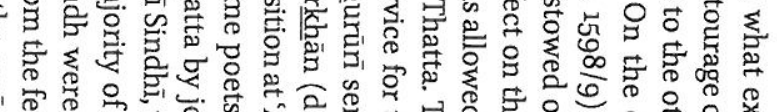

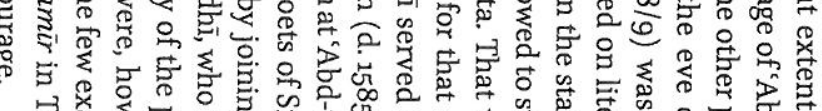

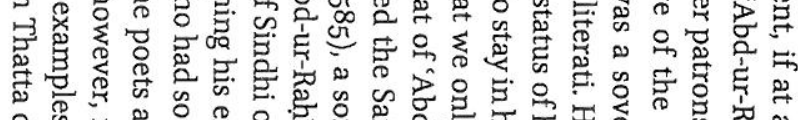

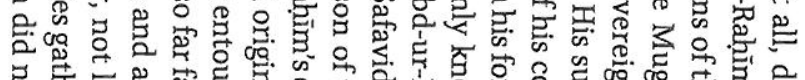

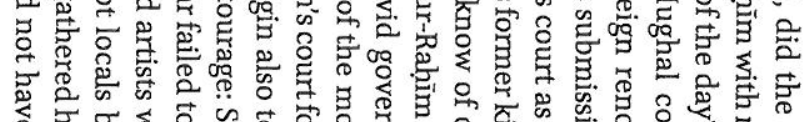

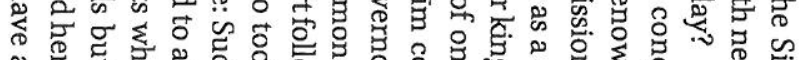

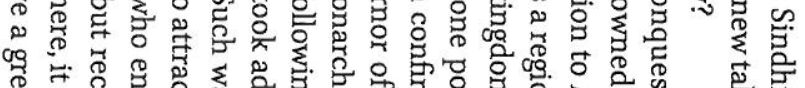

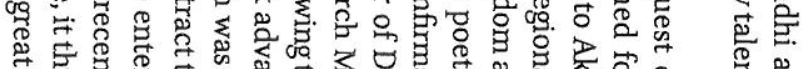

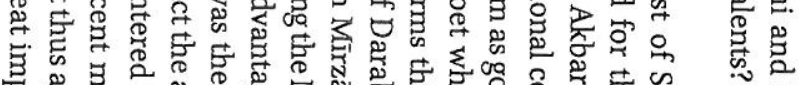

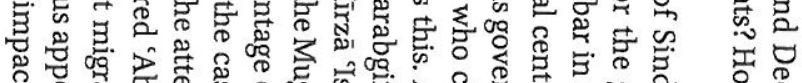

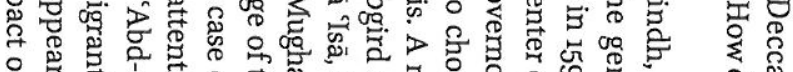

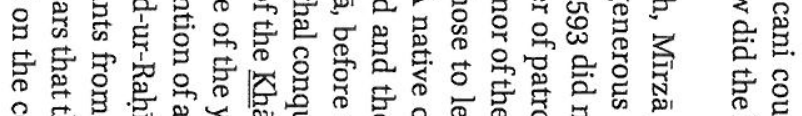

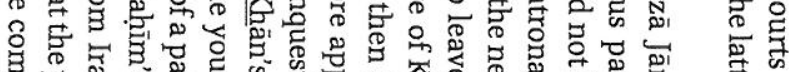

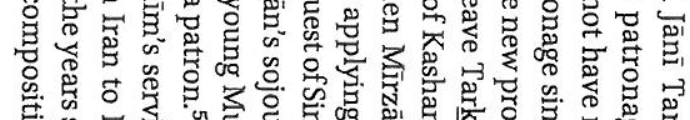

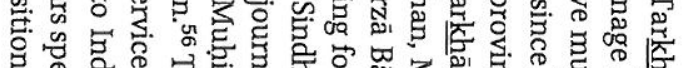

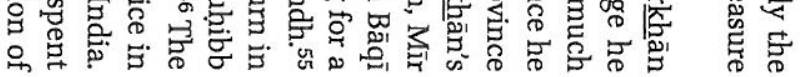

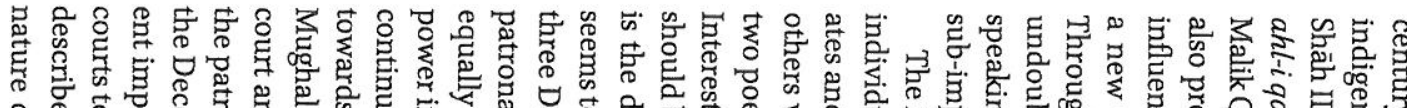

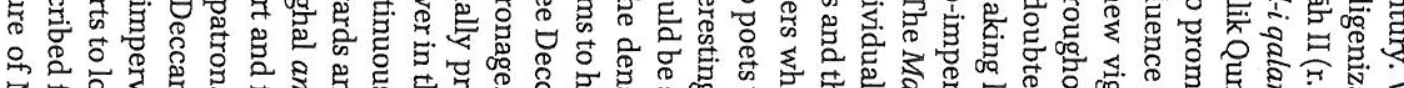

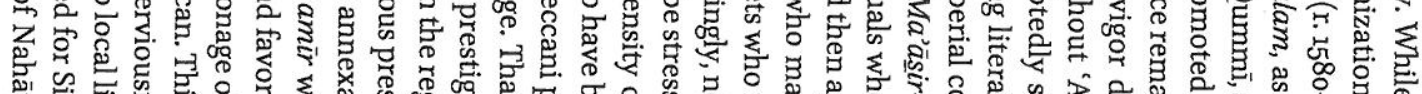

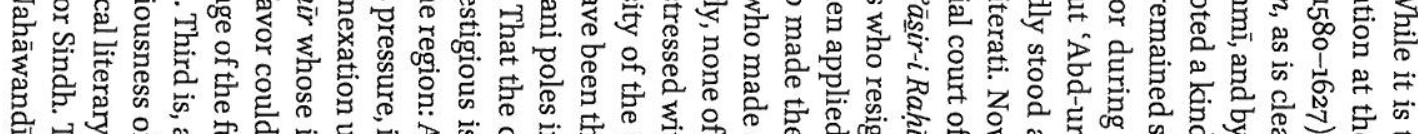

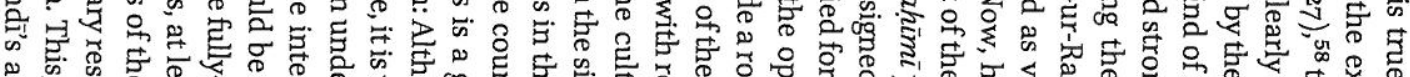
类.

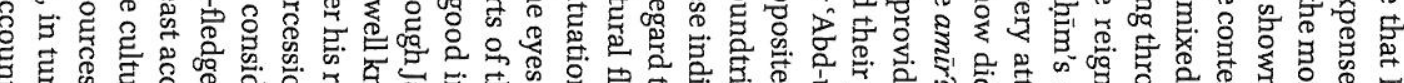

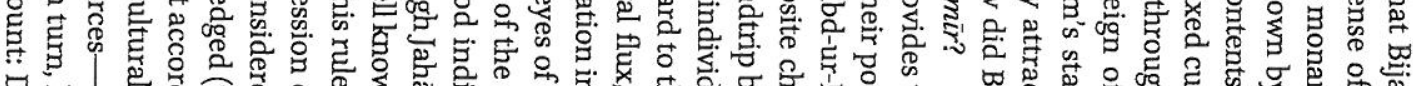

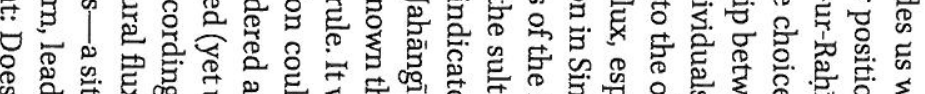

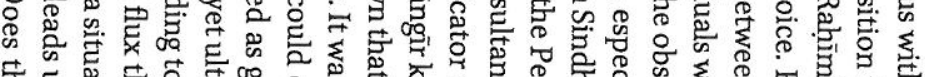

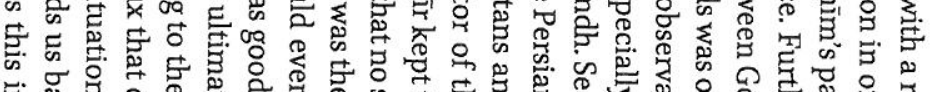

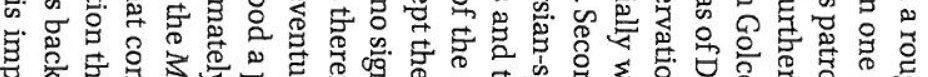

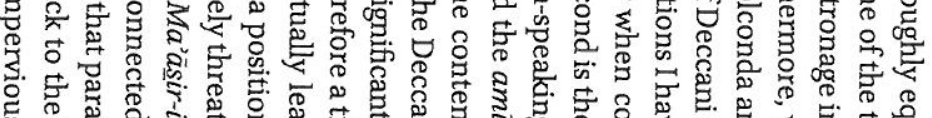

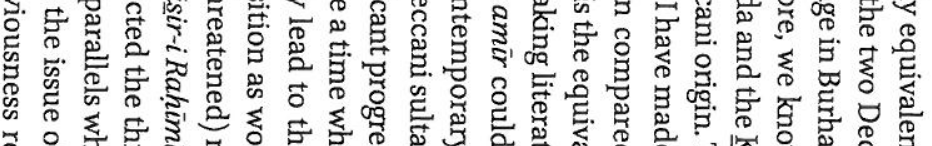

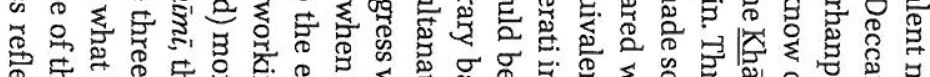

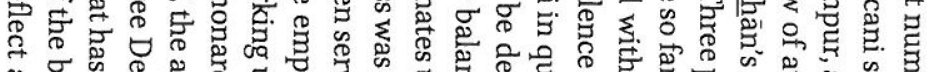

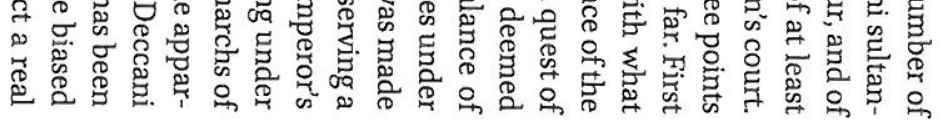

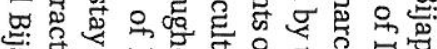

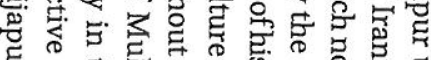

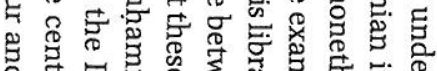

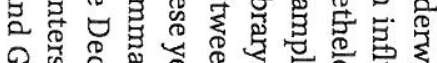
क क

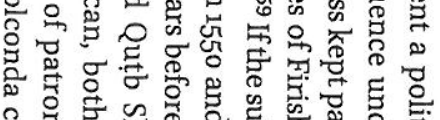

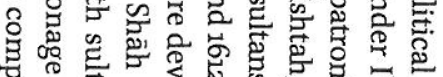

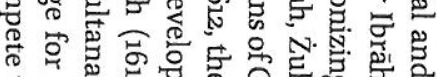

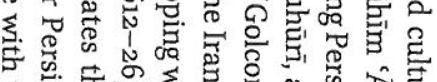

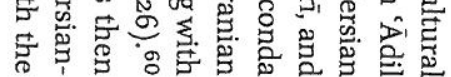



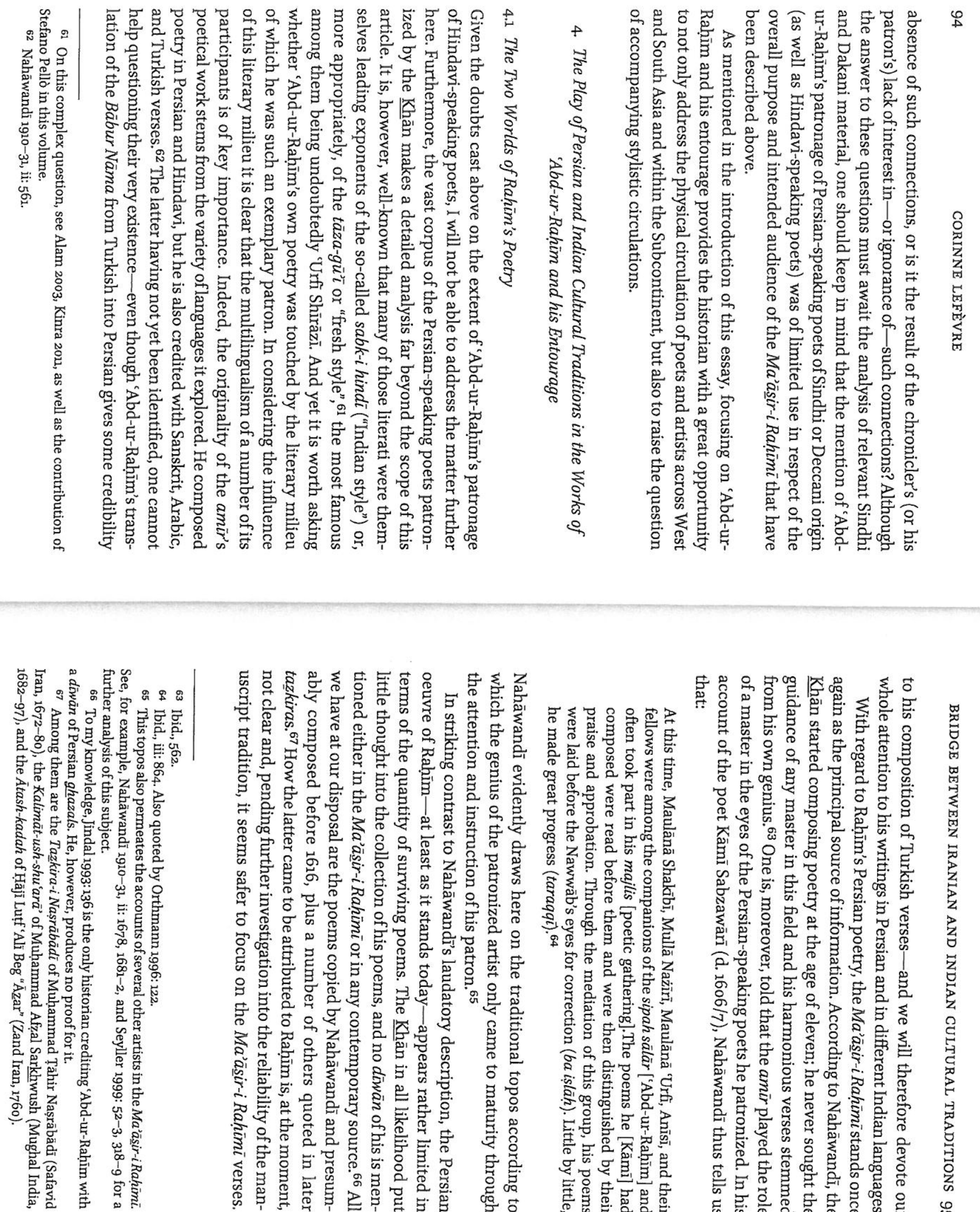

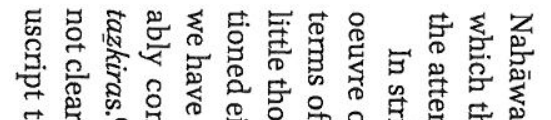

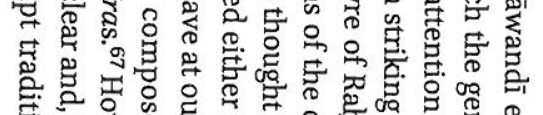

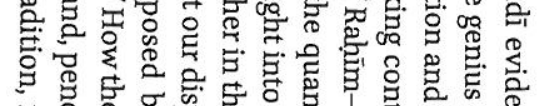

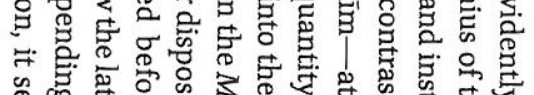

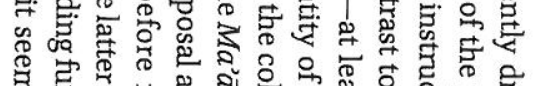

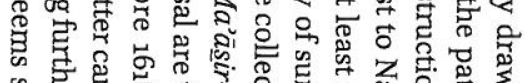

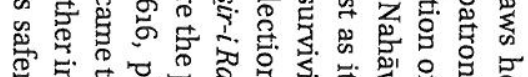

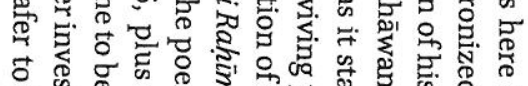

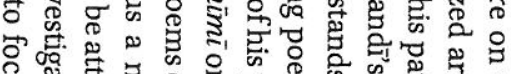

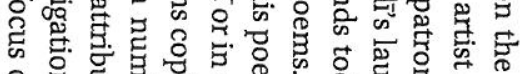

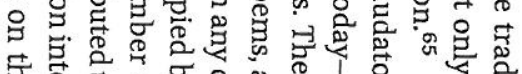

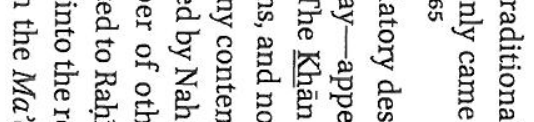

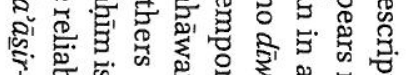

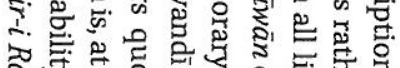

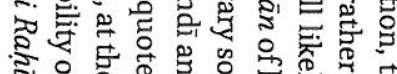

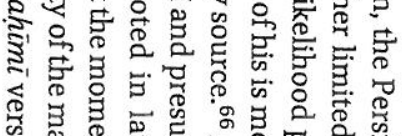

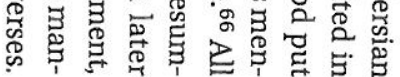

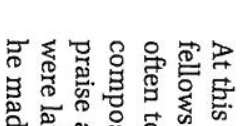

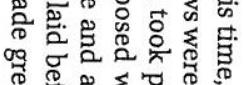

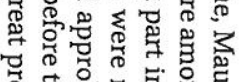

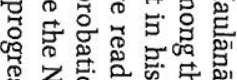

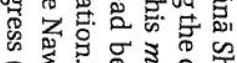

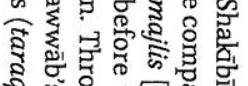

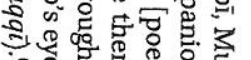
\&

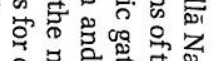

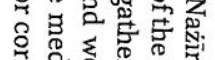

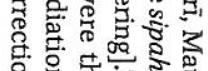

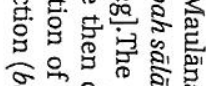

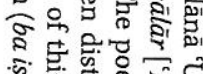

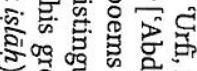

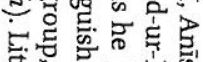

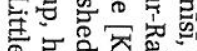

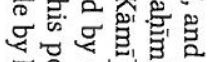

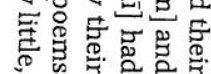

声 焉它氙

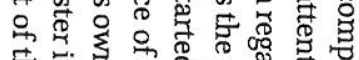
F

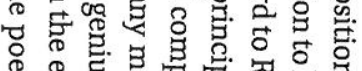
\$ 刃

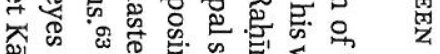

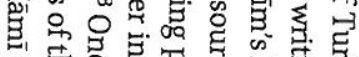

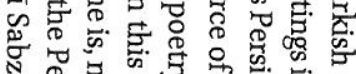

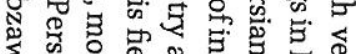

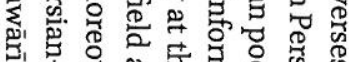

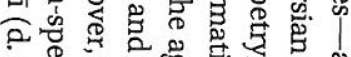

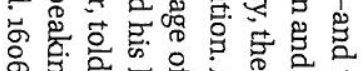

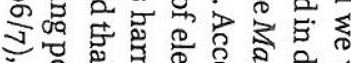

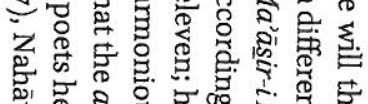

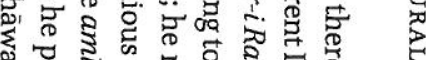

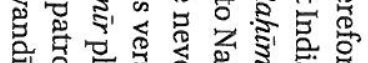

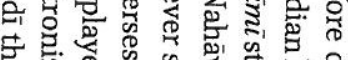

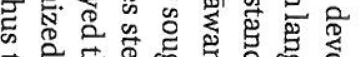

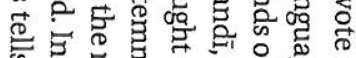

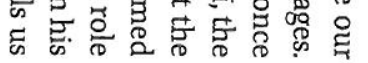




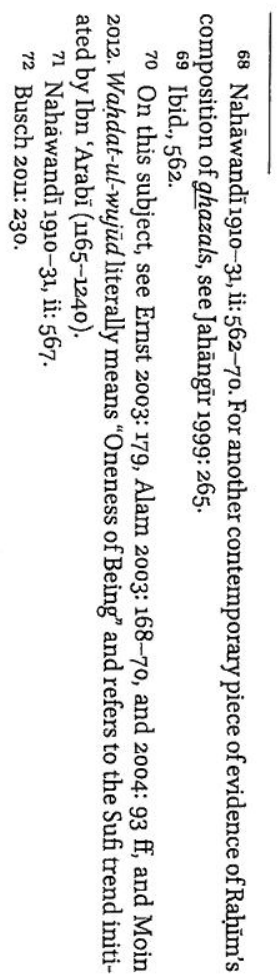

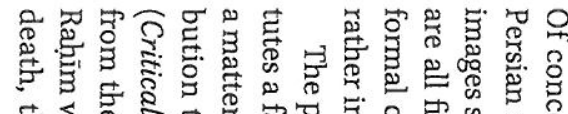

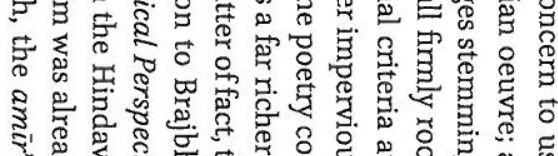

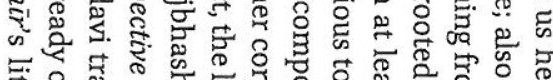
誌造范

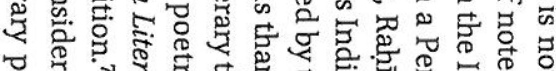

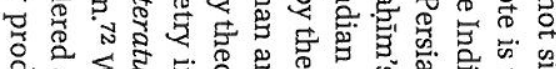

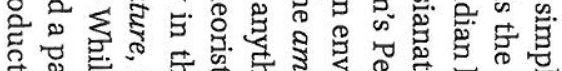

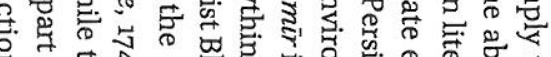

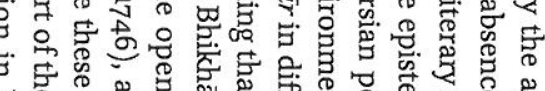

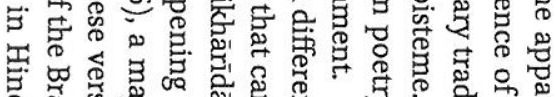

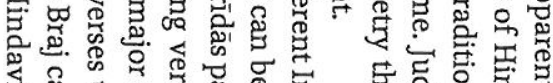
క. की

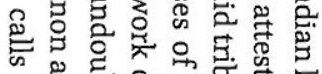

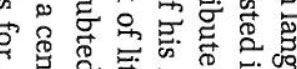

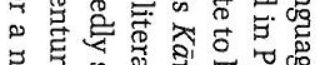

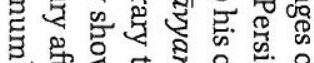

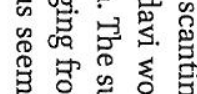

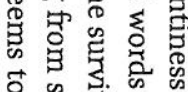

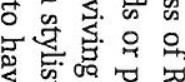

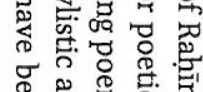

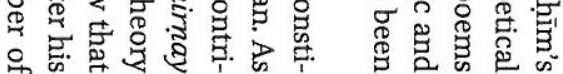

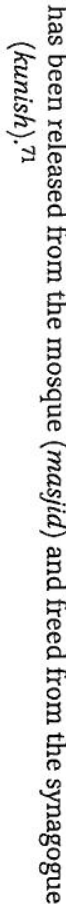

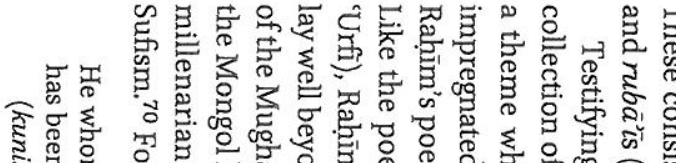

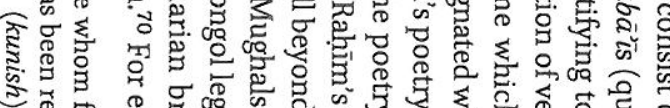

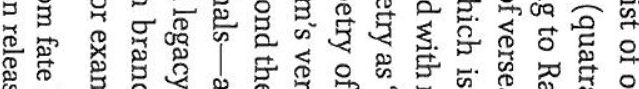

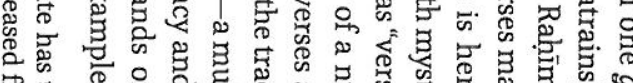

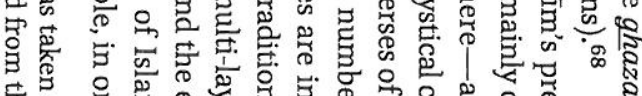

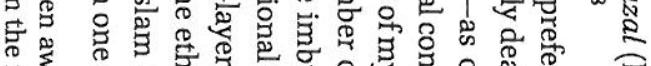

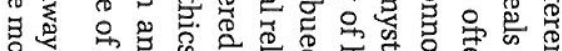

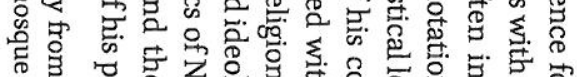

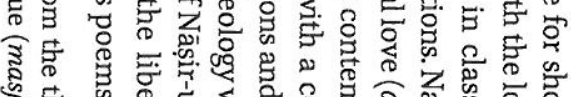

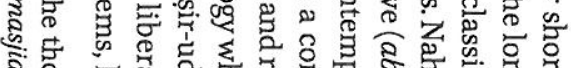

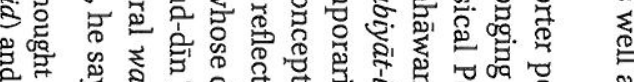

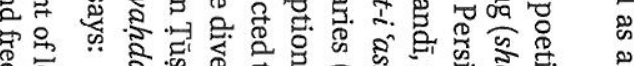

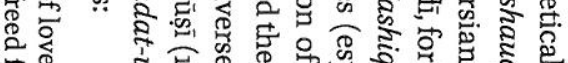

क्ष ड़ी है

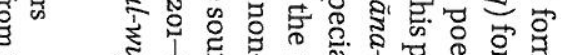

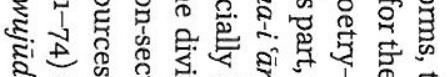

要

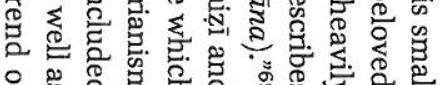

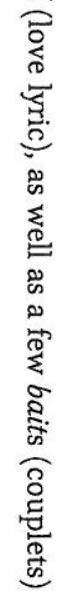

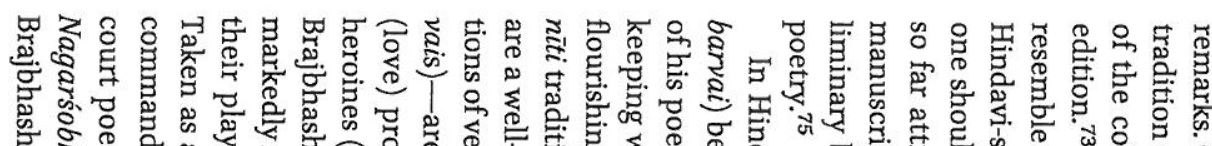

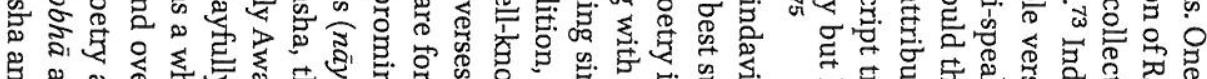

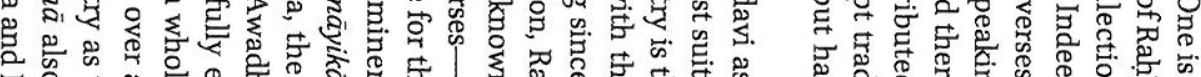

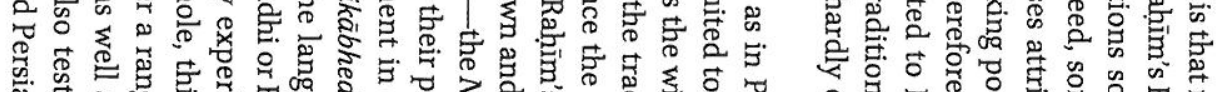

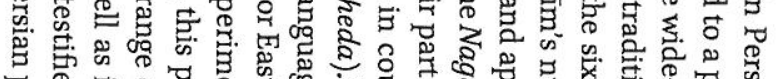

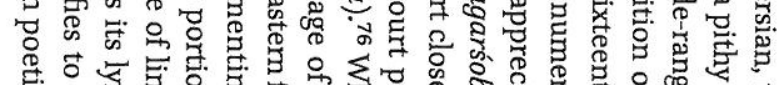

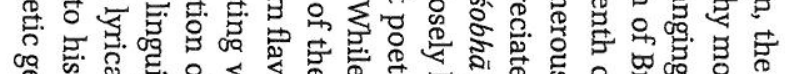

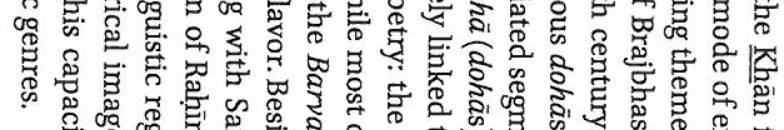

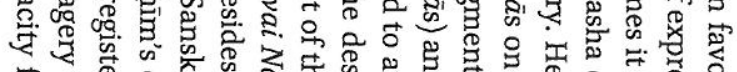

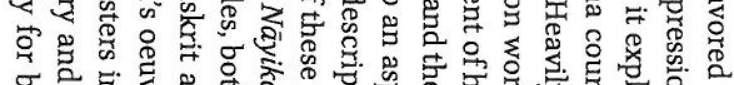

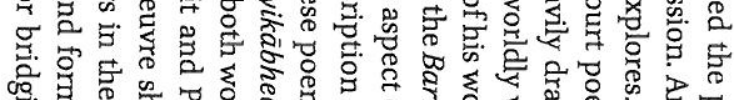

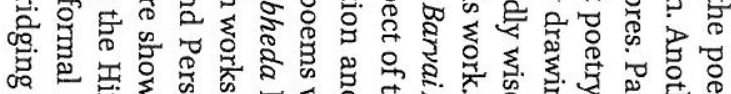

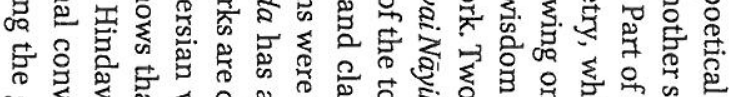

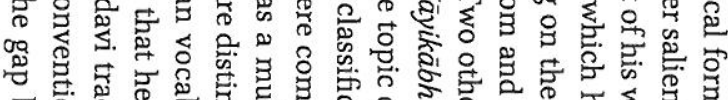

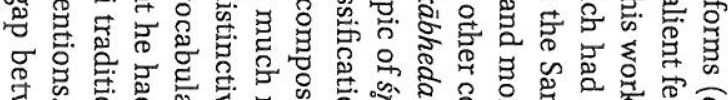

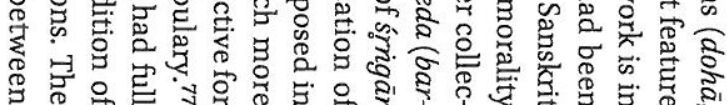

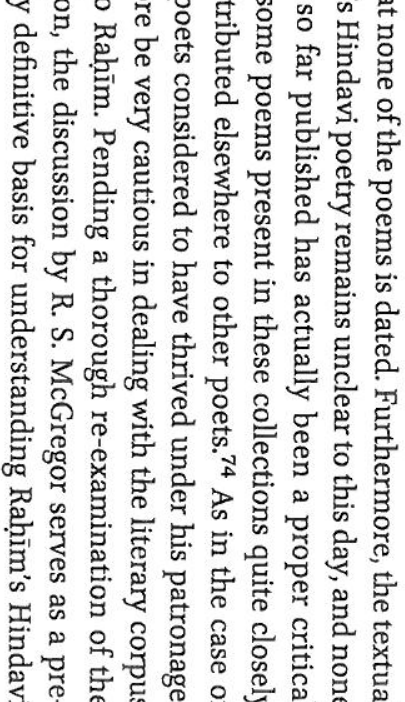




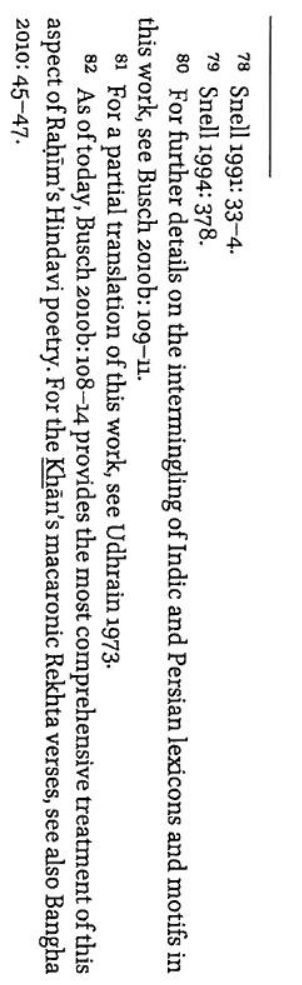

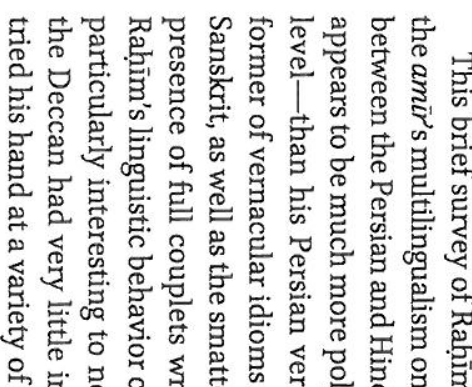

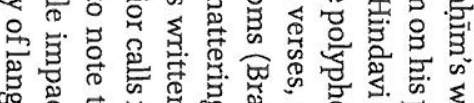

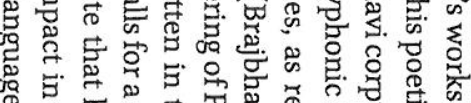

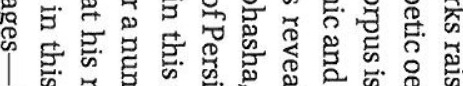

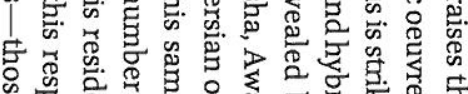

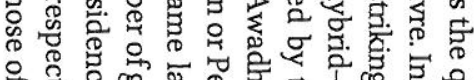

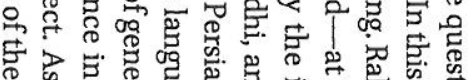

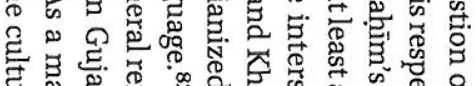

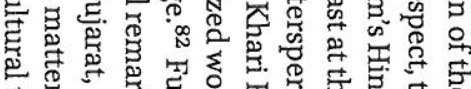

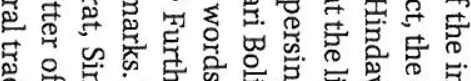

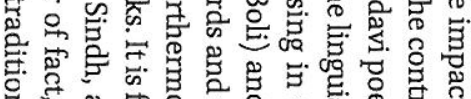

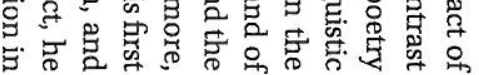

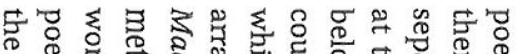

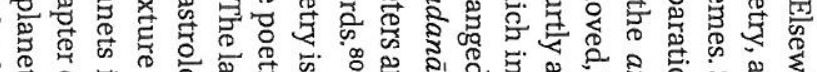




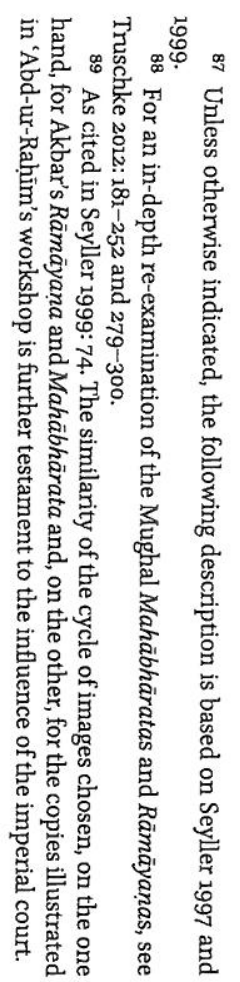

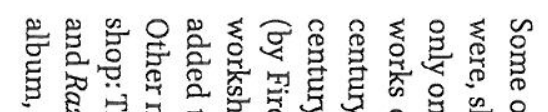

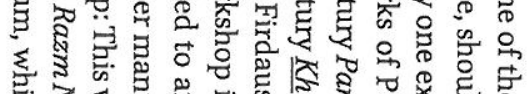

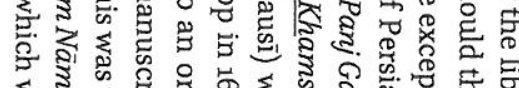

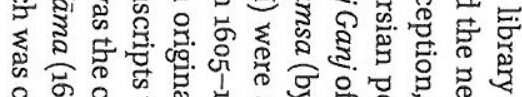

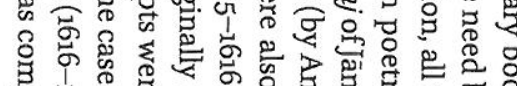

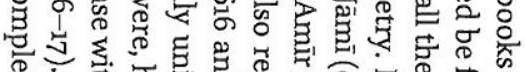

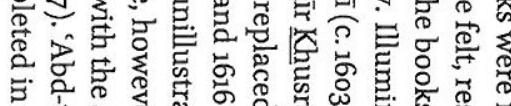

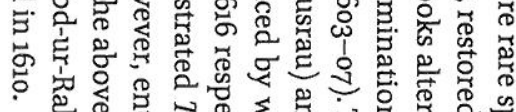

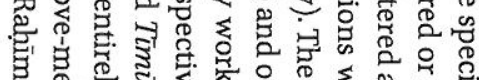

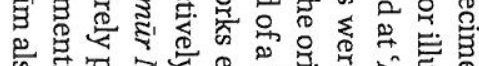

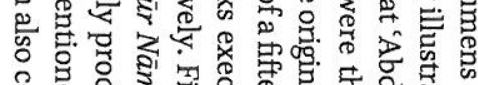

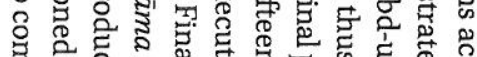

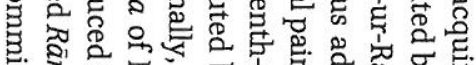

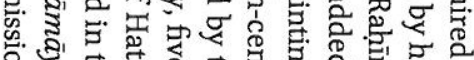

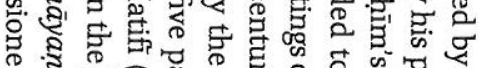

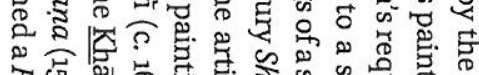

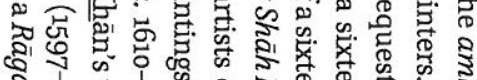

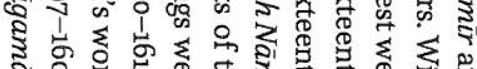

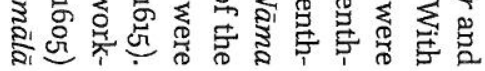

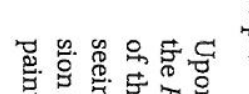

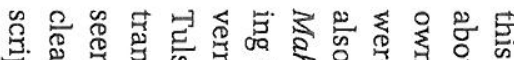
प्र

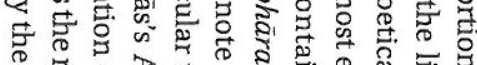

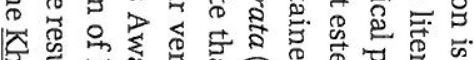

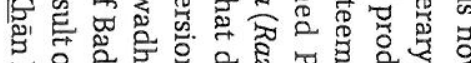

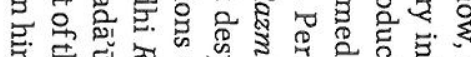

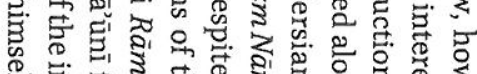

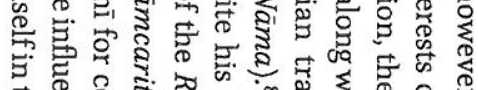

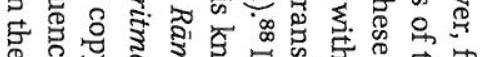

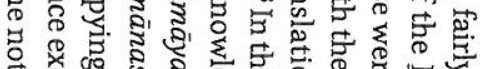

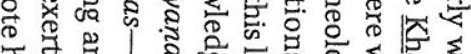

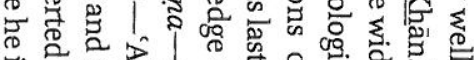

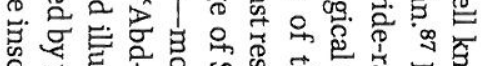

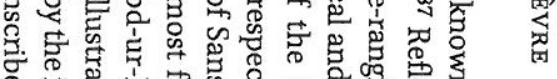

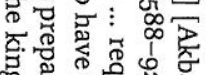

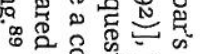

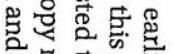

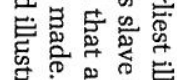

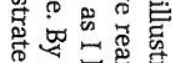

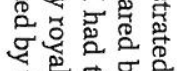

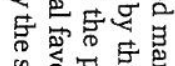

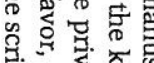

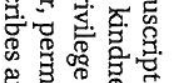

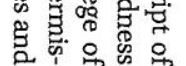

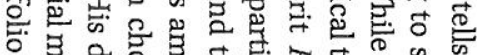

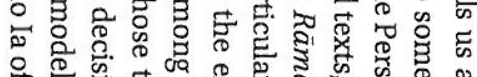

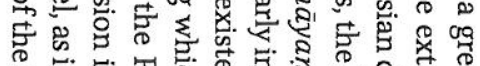

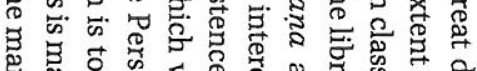

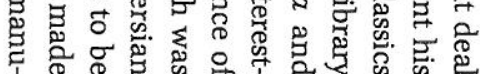

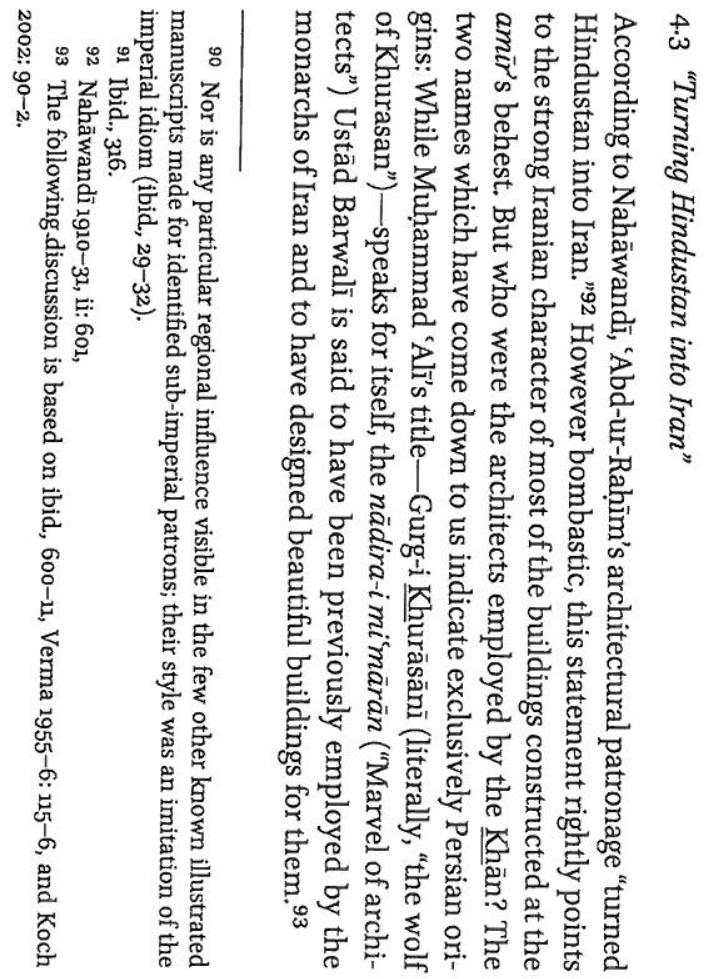

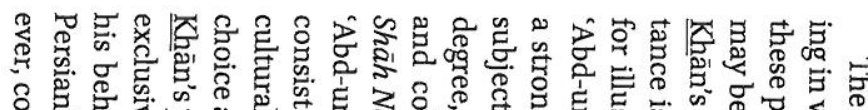

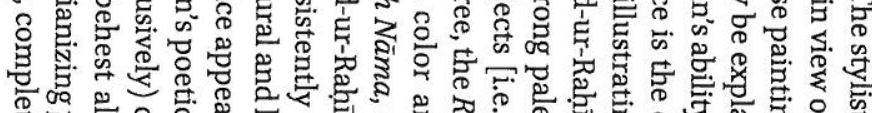

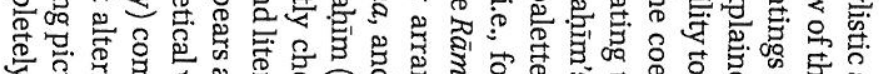

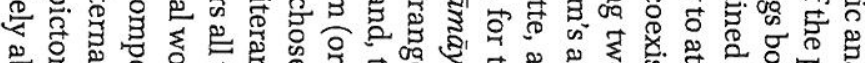

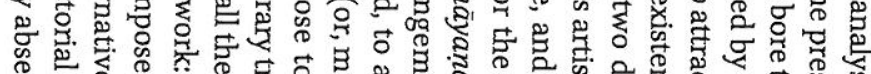

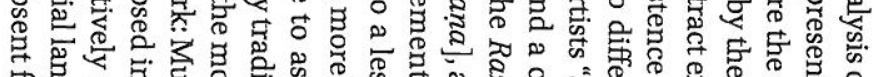

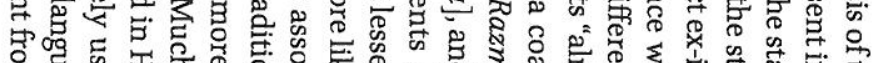

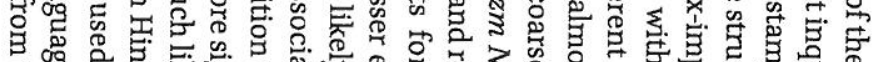

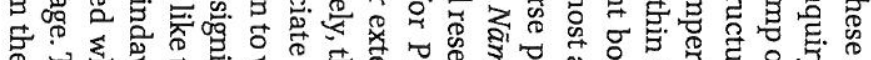

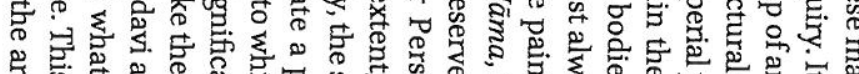

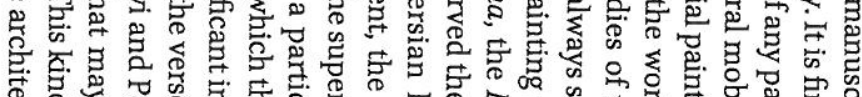

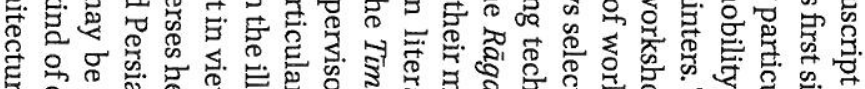

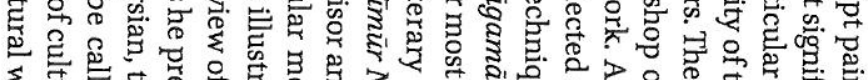

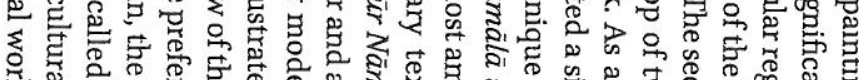

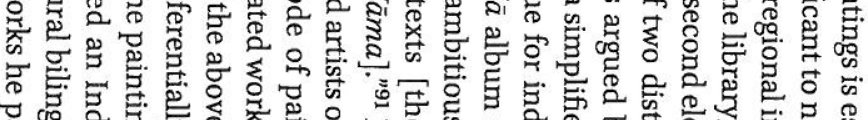

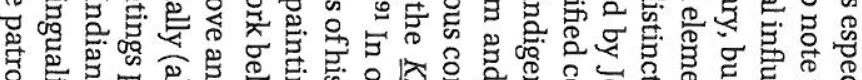

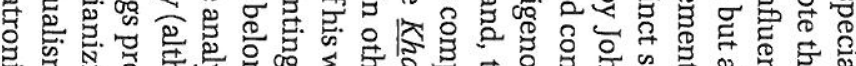

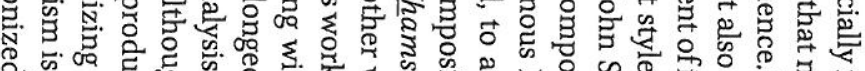

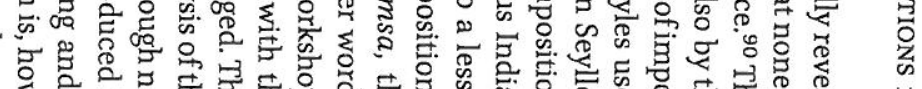

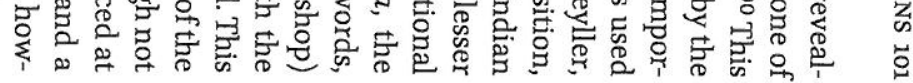



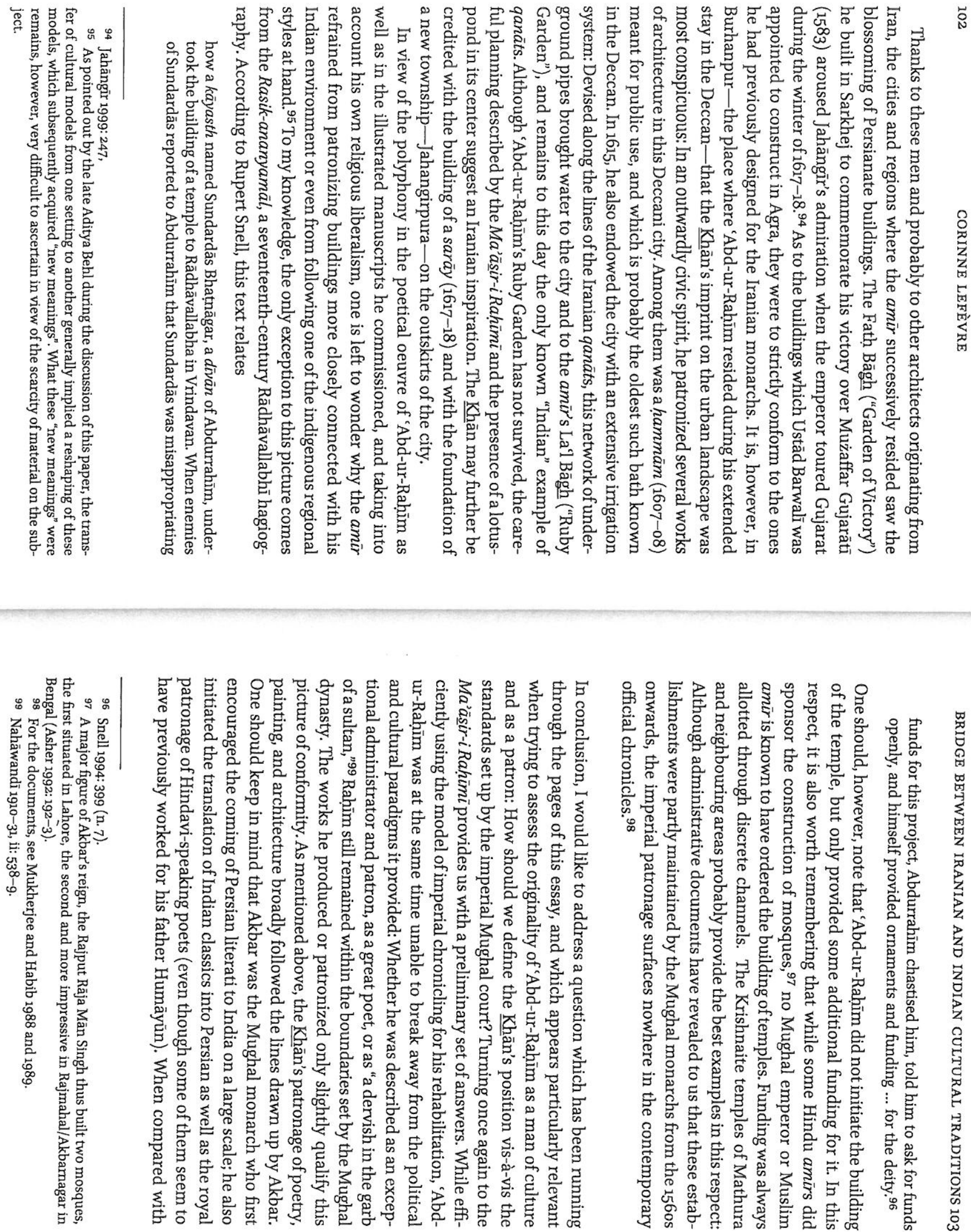


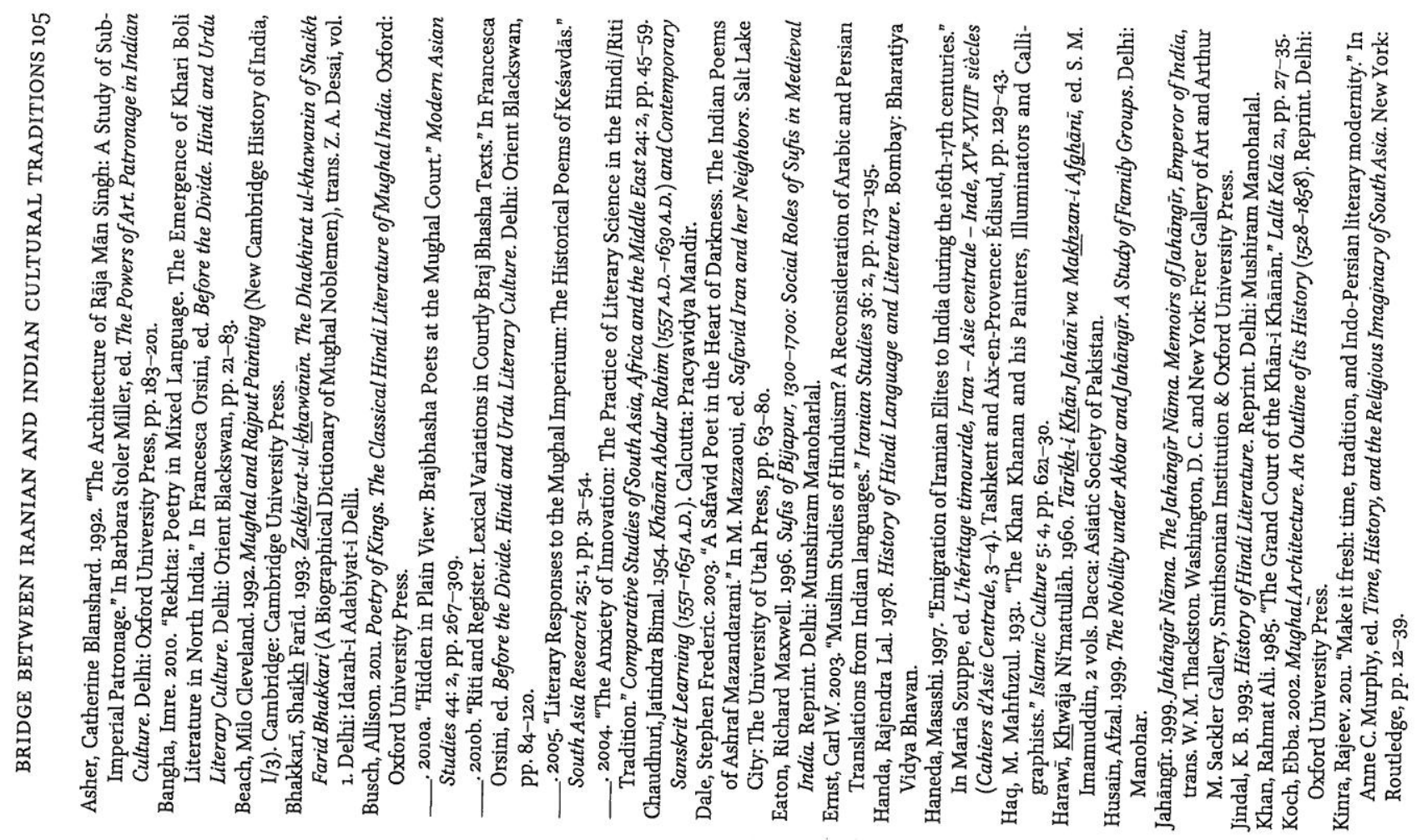

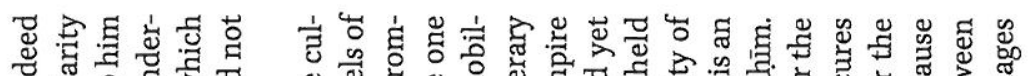

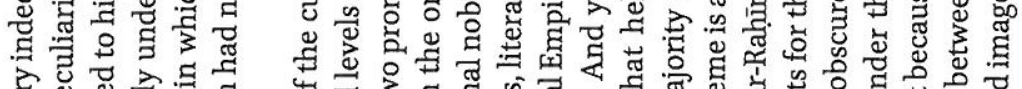

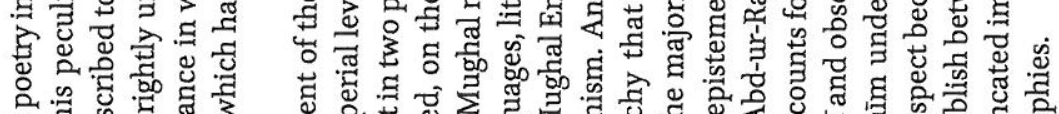

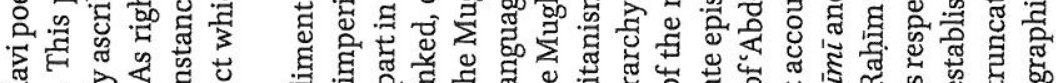

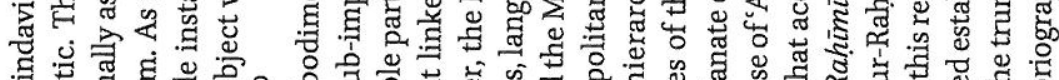

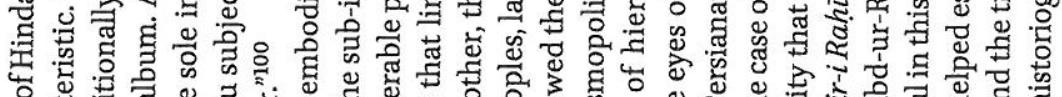

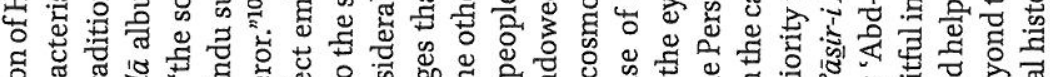

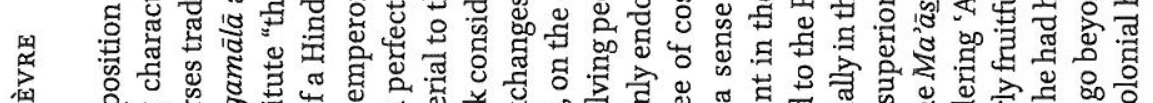

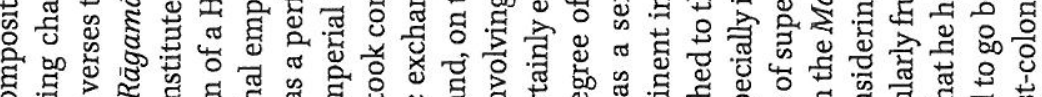

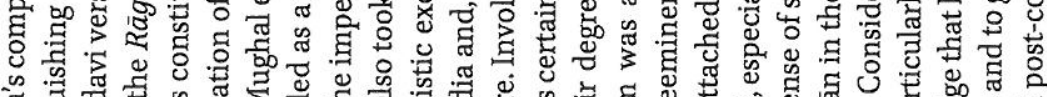

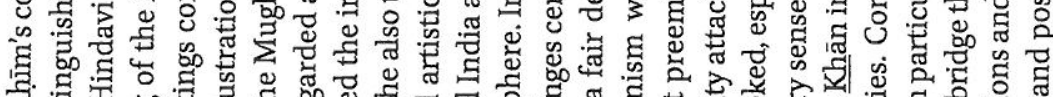

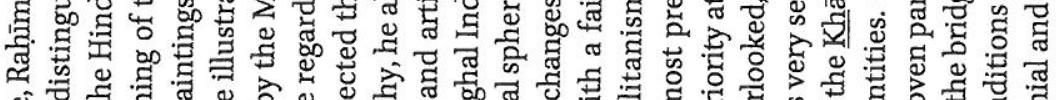

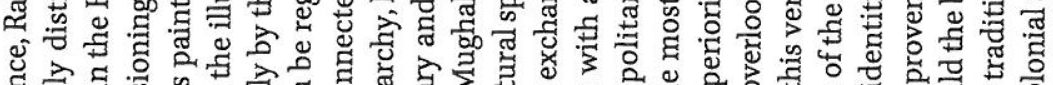

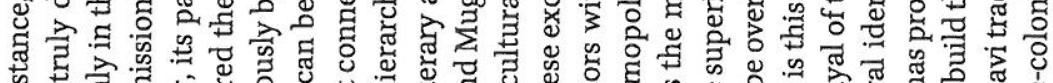

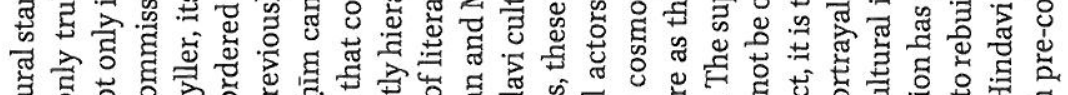

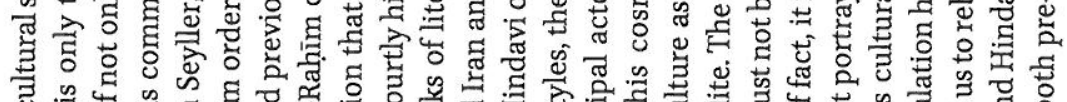

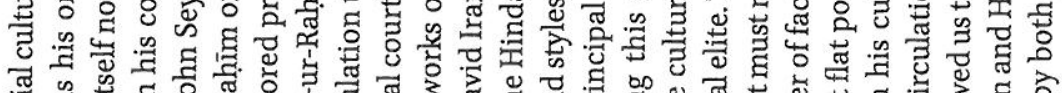

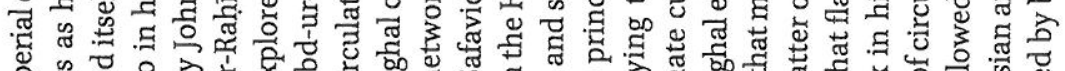

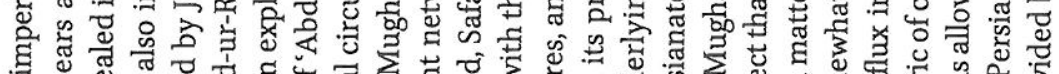

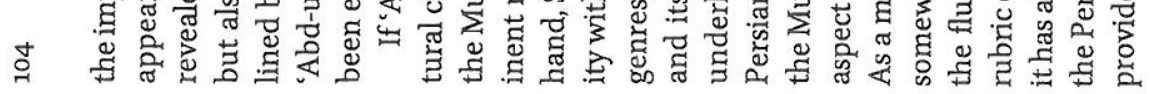

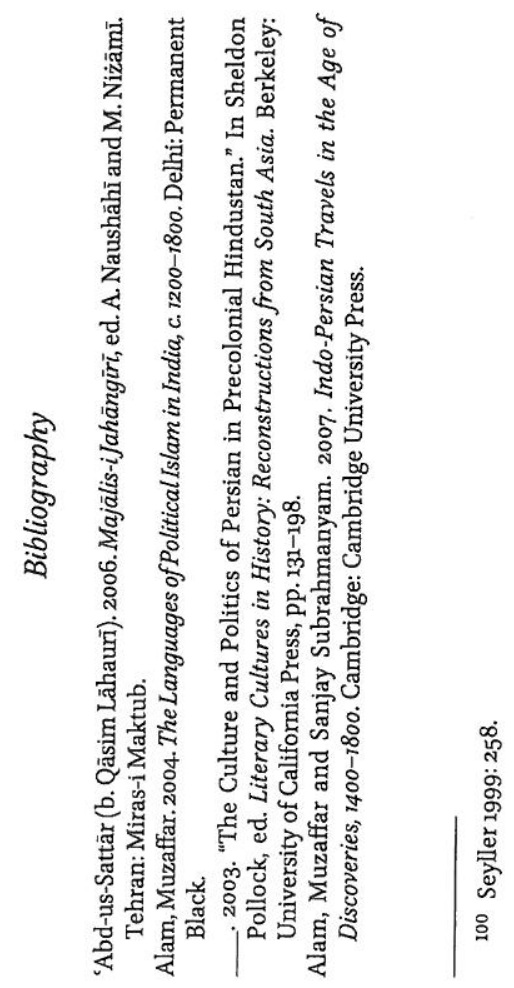




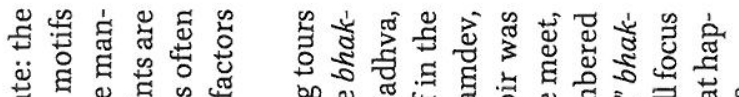

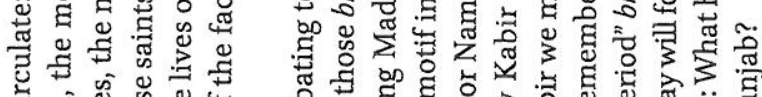

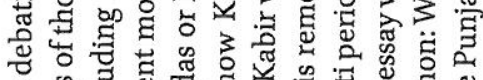

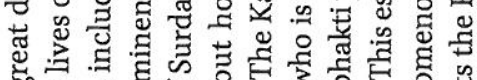

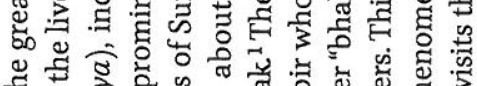

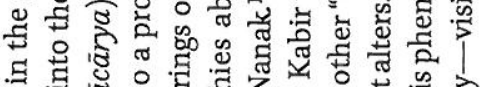

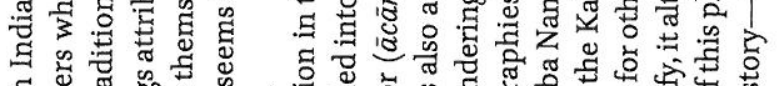

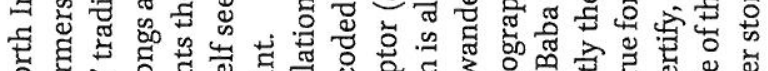

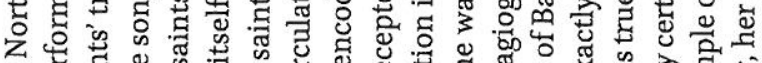

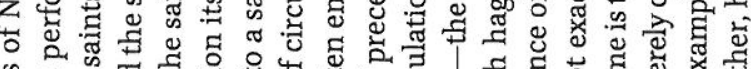

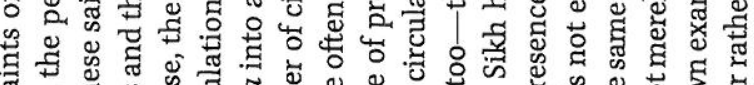

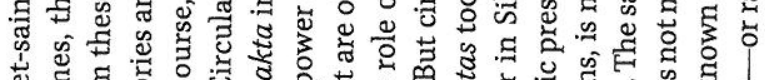

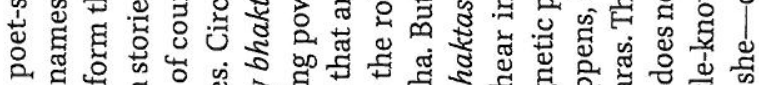
ฐ

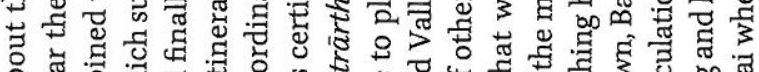

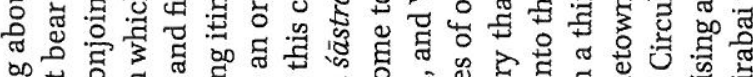

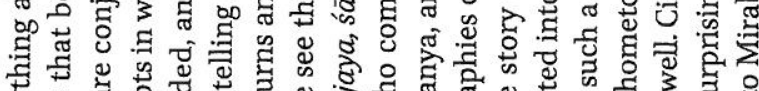

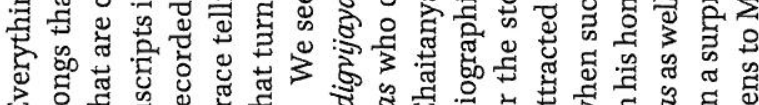

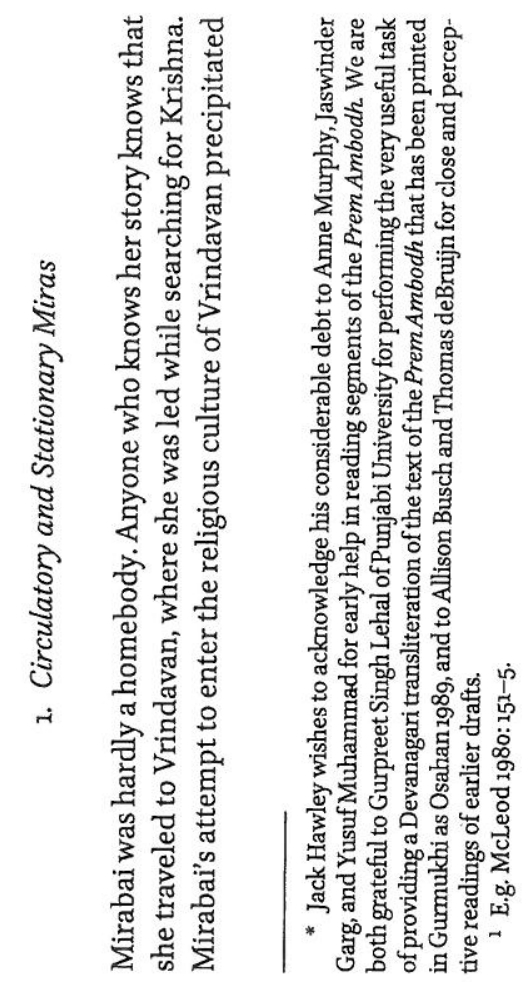

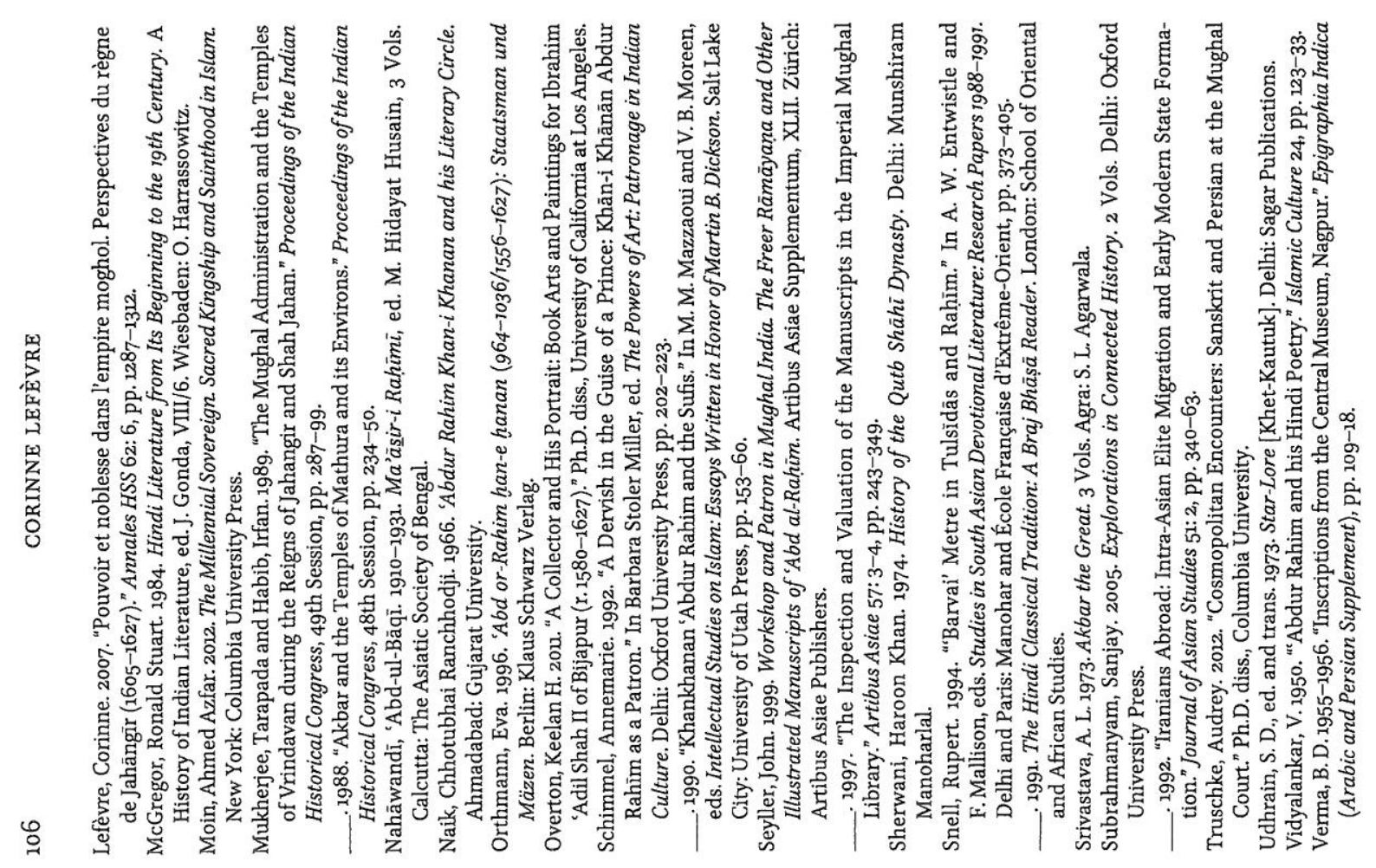

